$$
\begin{aligned}
& \text { ملامح تقارب الفتح والسكون في العربيَّة } \\
& \text { وداد بنت أحمد بن عبد الله القحطاني } \\
& \text { جامعة الدلك سعود }
\end{aligned}
$$

$$
\begin{aligned}
& \text { مستخلص يهذف موضوع البحث " ملامح تقارب القتح والسكون في العربيَّة" للكثف عن أوجه العلاقة التي }
\end{aligned}
$$

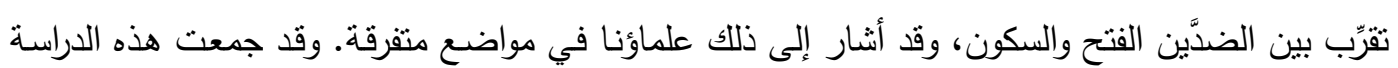

$$
\begin{aligned}
& \text { أنثتات هذه العلاقة، فظهرت في الأوجه الآتية: }
\end{aligned}
$$

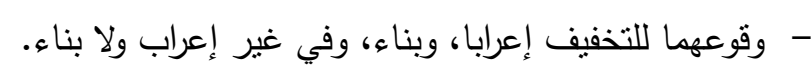

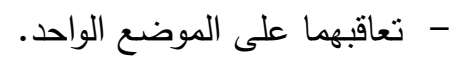

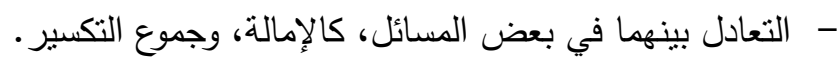

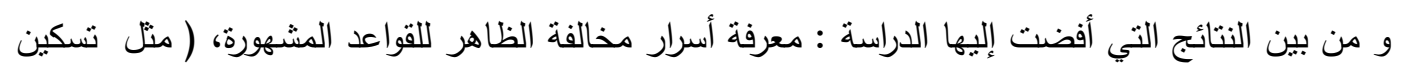

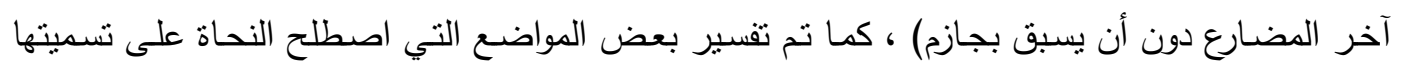
بالضرورة أو الثذوذ، (وهي عند فصحاء العرب جائزة).

$$
\text { الكلمات المفتاحية: النحو العربي - الفتح - السكون. }
$$

وأساليبها وتراكيبها، فكُلُ أولئك له دلالة ومعنى يدفع

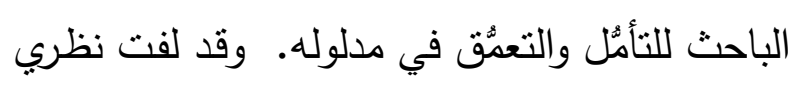
- أثناء تأمُّلاتي في الموضوع - ما خلَّفه أبو الفتح بـن جني مسن تراث عظيم، سَبَق بنظره كثيرًا مـن

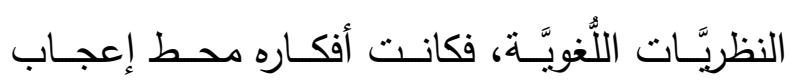

\section{المقدمة}

إنَّ اللَّسان العربي يتميَّز عن سـائر الألسُن بخصائص لم توجد في غيرها من الألسن السَّاميَّة؛ السئ

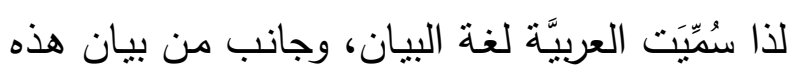

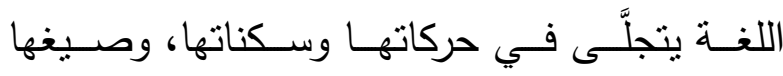


موضـع ـ نحويًَا وصرفيًاًا ـ يمكن أن يلتقيا فيهـ أو

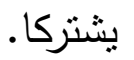

وقد اقتضت طبيعة البحث أن يأتي على النََّتق الآتي:

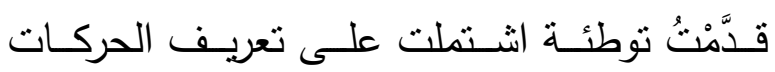

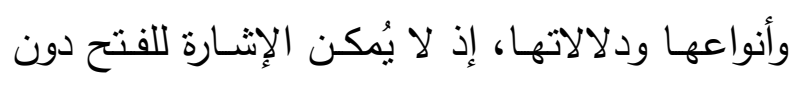
التطرق لأخويه، وأعقبتها بتعريف السكون ودلالآنه، الإنها

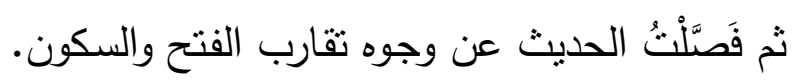

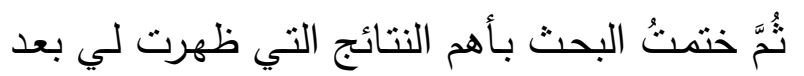

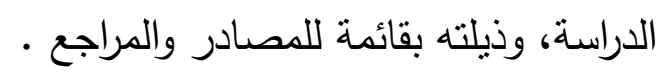

\section{الحركة: تعريفها وأنواعها، ودلالاتها(1).:}

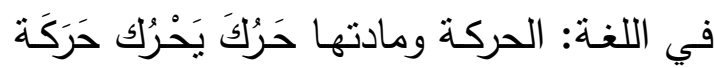

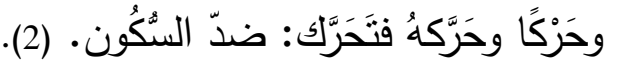

أرَّا في مصطلح الدنقدمين فلم يكن لها أثر في

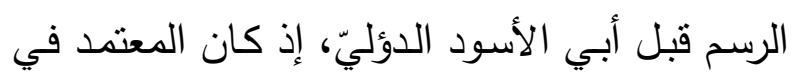

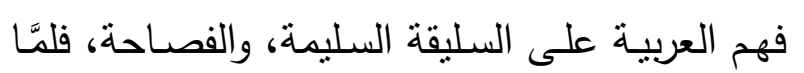

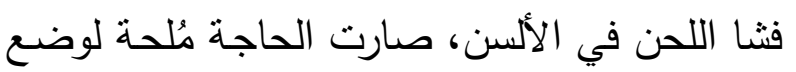

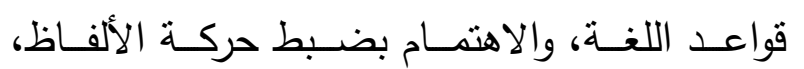

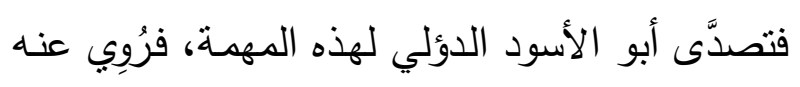

(1) ينظر تفصيل ذلك في البحث القيم لعبدالرحمن محمد

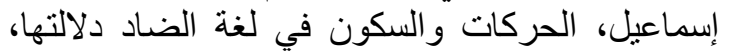

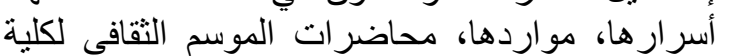
اللغة العربية، جامعة أم القرى، مكة المكرمة، المرا، 1420ه ـ 1999م. - م

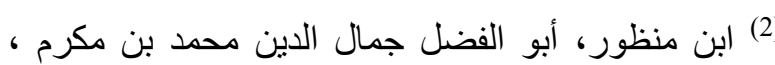

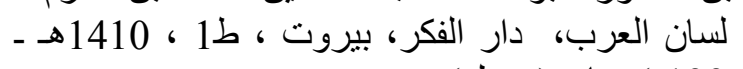

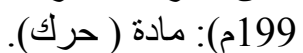

المسـتعربين والمستتـرقين، وغـــا مَنْن بعـده عيـالا

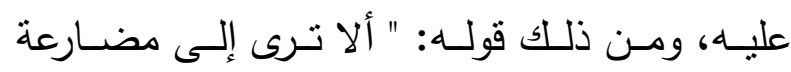

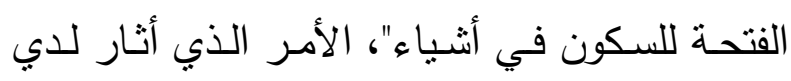
سؤالا: كيف تتضارع الحركة الفتح مـع عدم الحركة التهرئ

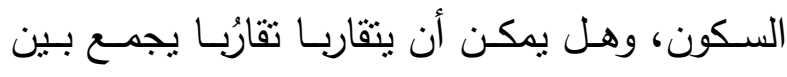

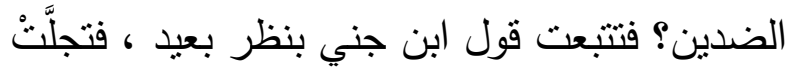

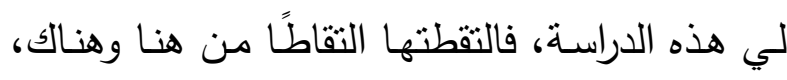

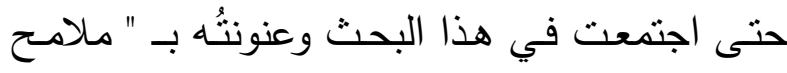

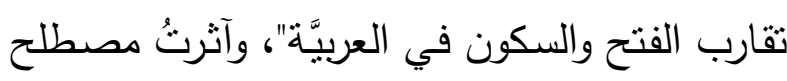

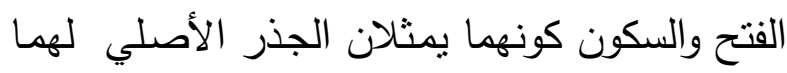

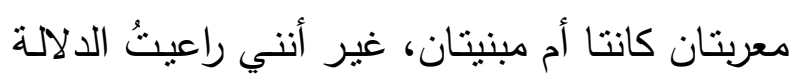
في مواضع الإعراب والبناء( النصب، والجزم). ولم أكن في هذه الدراسة بِدعا، فقد وققت على

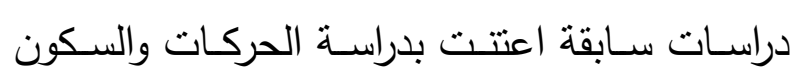
منها على سبيل المثال: الحركات والسكون في لغة لغنة

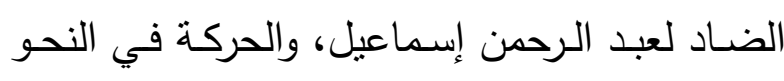
العربـي لعدـر حسـن أبـو شـهبة، والحركـات بـين القدامى والمحدثين لصبيح حمود الثنَّاتي، والحركات في اللغـة العربية دراسـة في التشكيل الصـوتي لزيد خليل القرالة وغيرها من الأبحاث التي اهتمت بدراسة دربة

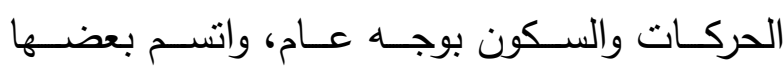
بالدراسة المقارنة بين القديم والحديث، ولم أجد بحثًا

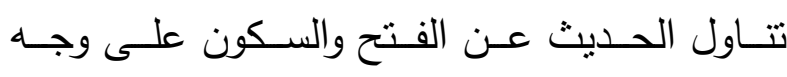
الخصوص، فكانت هذه الدراسـة تهدف إلى كثف

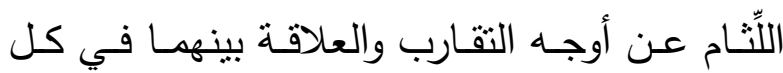


يقول سيبويه:" وكلَّمَا توالت الحركات أكثر كـان

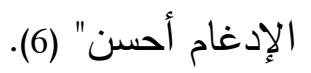

وقد وضّح الخليل دور الحركات دون أن يُنشير إلى مصطلح الحركة، قال عنه سييويه:" وزعم الخليل أنَّ الفتحة والكسرة والضمة زوائد، وهنَّ يلحقن الحرف؛

$$
\text { ليوصل إلى التكلم به" (7). }
$$

فدورها يظهر جليَّا في تمكين الناطق من إحداث

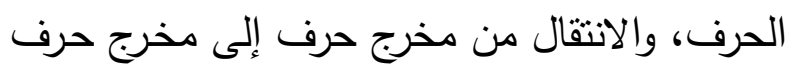

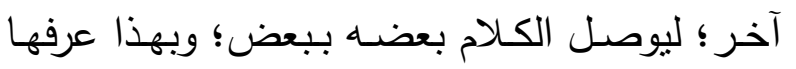

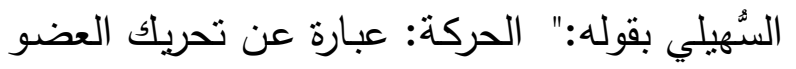

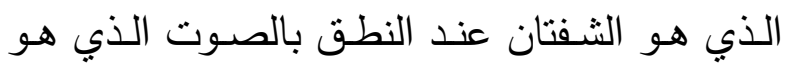

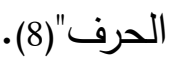
ويظل هذا المصطلح غير محدد إلى أنْ جاء ابن جني واهتم بدراسة الأصوات ومن ضمنها الحركات في كتابيه: الخصائص، وصناعة الإعراب، فيقول

(6) سييويه، أبو بشر عمرو بـن عثمـان بـن قتبر ، الكتاب،

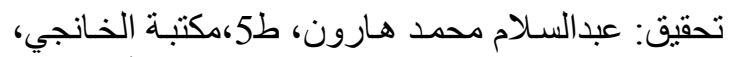
القاهرة،1430هـ ـ 2009م: 437/4، وينظر أيضًا: 14 .340،339 (7) (7) المصدر السابق: 241/4-339، 242.

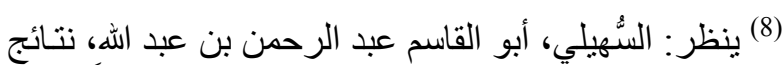

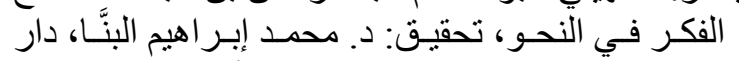

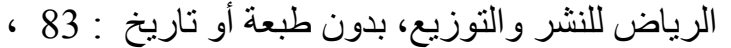

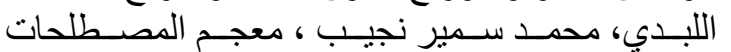

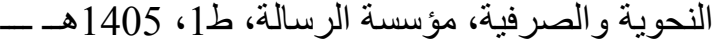

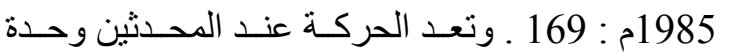
صوتية منطوقة مسمو عة، ينظر : سعد مصلو حَ، دراستة

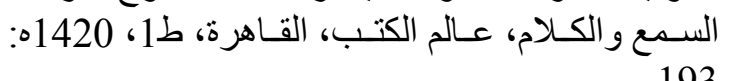

أنَّهَه قال لكاتبه:" خُذْ المُصحف وصبغًا يُخالف لون المداد، فإذا فتحتُ شفتيّ فانقط واحدة فوق الحرف، وإذا ضممنُها فاجعل النقطة إلى جانب الحرف، وإذا كسرتهما فاجعل النقطة أسفله، فإنْ أنبعتُ شيئًا من إن هذه الحركات غُنَّة فانقط نقطنين" (3). فــأبو الأسـود وضــع الــقط للحركـة حسـب الأداء النطقي لها، ثم تطور الأمر عند الخليل بن أحمد وطد

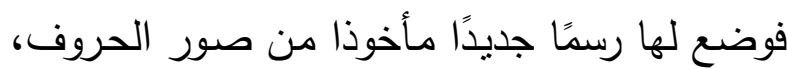
فالضمة واو صغيرة الصورة في أعلى الحرف؛ لئلا

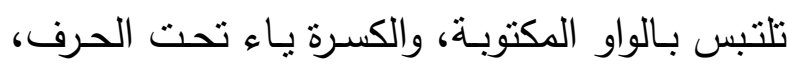
والفتحة ألف مبطوحة فوق الحرف(4). وعلى الرغم من إدراكهم الفرق بين هذا الحركات

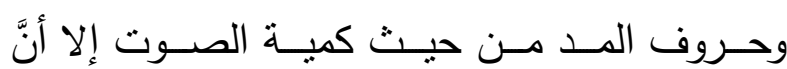

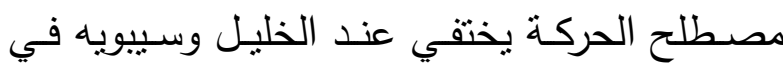

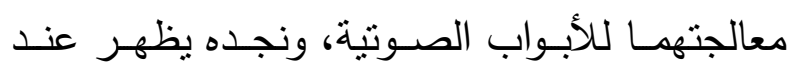
حديثهم عن الأبواب النحوية والصرفية (5).

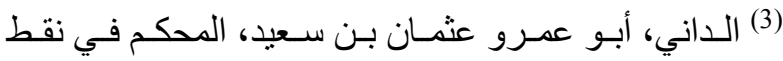

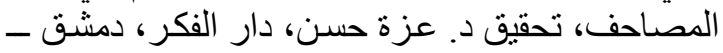

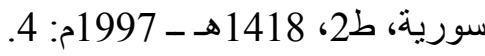
(5) المصدر السابق: 7.

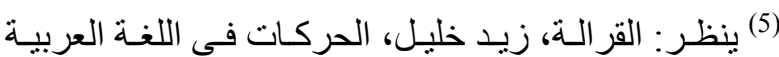

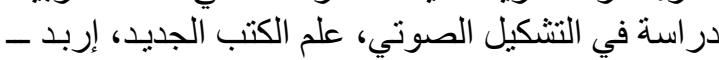
الأردن، ط1425،14هـ ــ 2004م: 7. 
أولاً: الفتح: "عبارة عـن فتح الثـفتين عند النطـق

بالحرف، وحدوث الصوت الخفي الذي يسمى فتحة

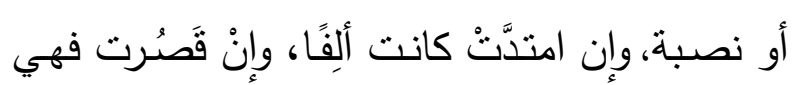

بعض ألف، وصـورتها كصـورة ألف صـغيرة"(12). فالفتح يكون صـوتا فقط في داخل البنيـة، مثنل: ضَرَبَ وقَََم، ويكون صوتا وعلامة للإعراب ، نحو

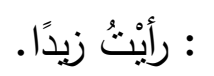

ثانياً: الضم: وهو "عبارة عن تحريك الثفتين بالضم

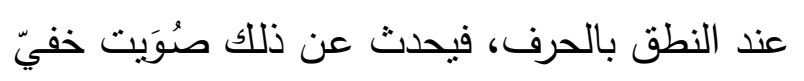

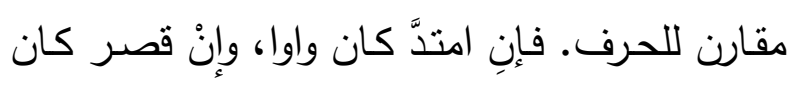

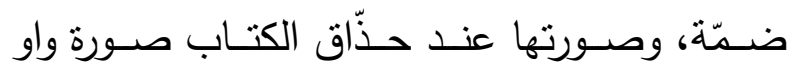
صغيرة؛ لأنّها بعض الواو "(13). ثُالثاً: الكسر : وهو عبـارة عن انزلاق اللسـان إلى الـى

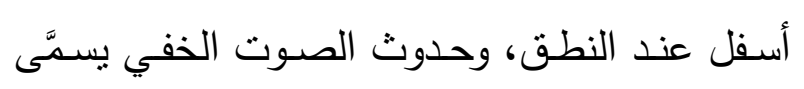

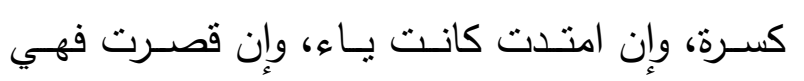
بعض ياء(14).

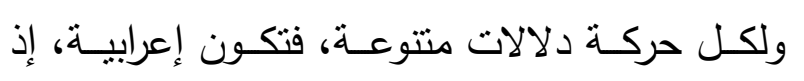
الفتحة علم الفضلات، والضمة علم الإسناد، والكسرة

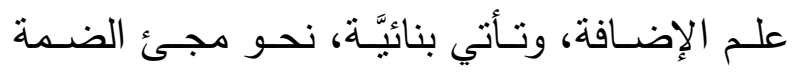

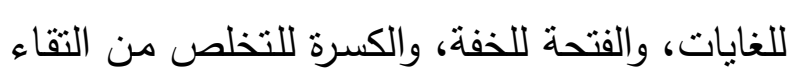

(12) ينظر : السهيلي، نتائج الفكر : 84.

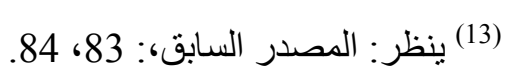
(14) ينظر: اللبدي، معجم المصطلحات النحويـة والصـرفية:
مُعلِّلا لتسميتها بذللك:" وإنَّها سُمِيَت هذه الأصسوات

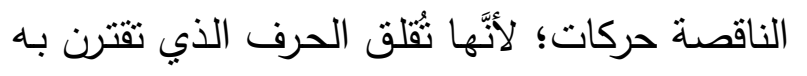

.(9)"

وقد أكَّد مـا ألمـح إليه الخليل بأنَّ الحركات أبعاض

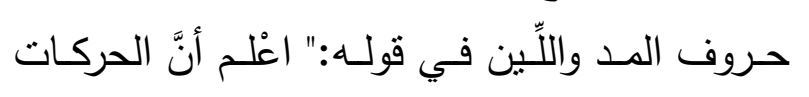

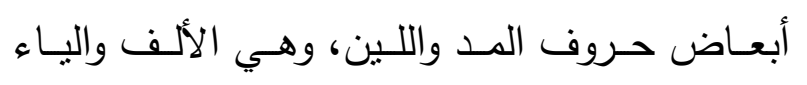
والواو ، فكما أنَّ هذه الحروف ثلاثة، فكذللك الحركات

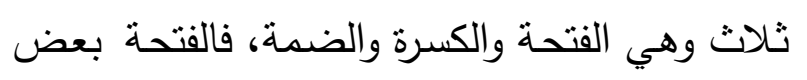

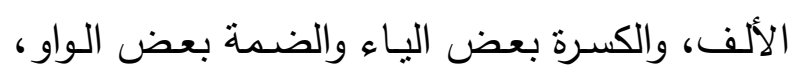

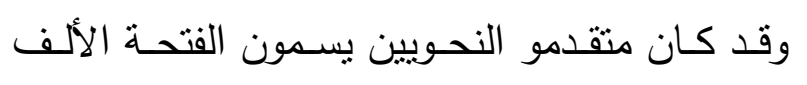

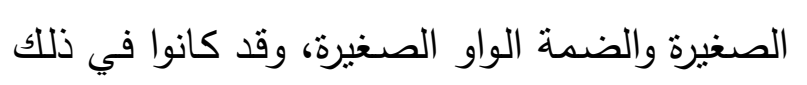

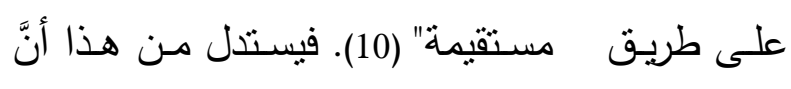

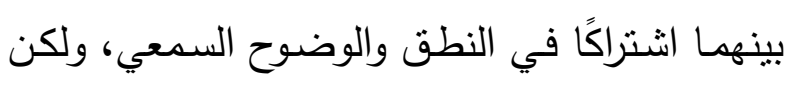

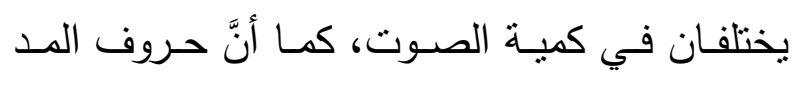

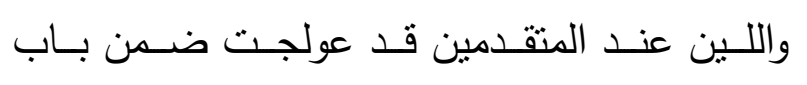

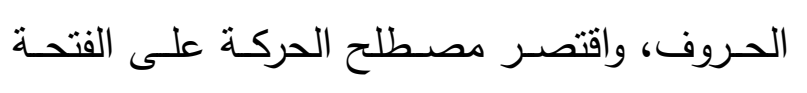
والضمة والكسرة(11). ومن منطلق مفهومهم للحركات

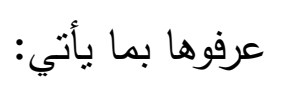

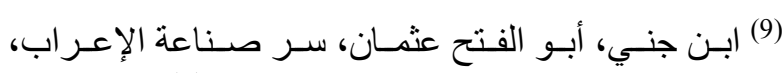

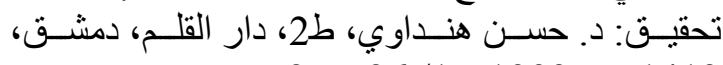
1413هـ - 1993م: 26 - 26 - 27.

(10) المصدر السابق: 17/1)

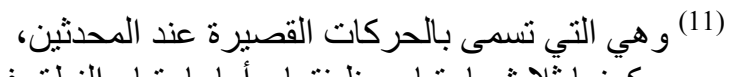

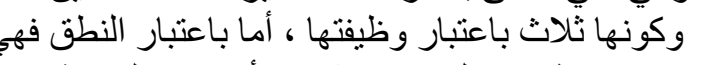

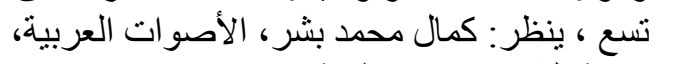
مكتبة الثباب، بدون طبعة وتاريخ: 149. 


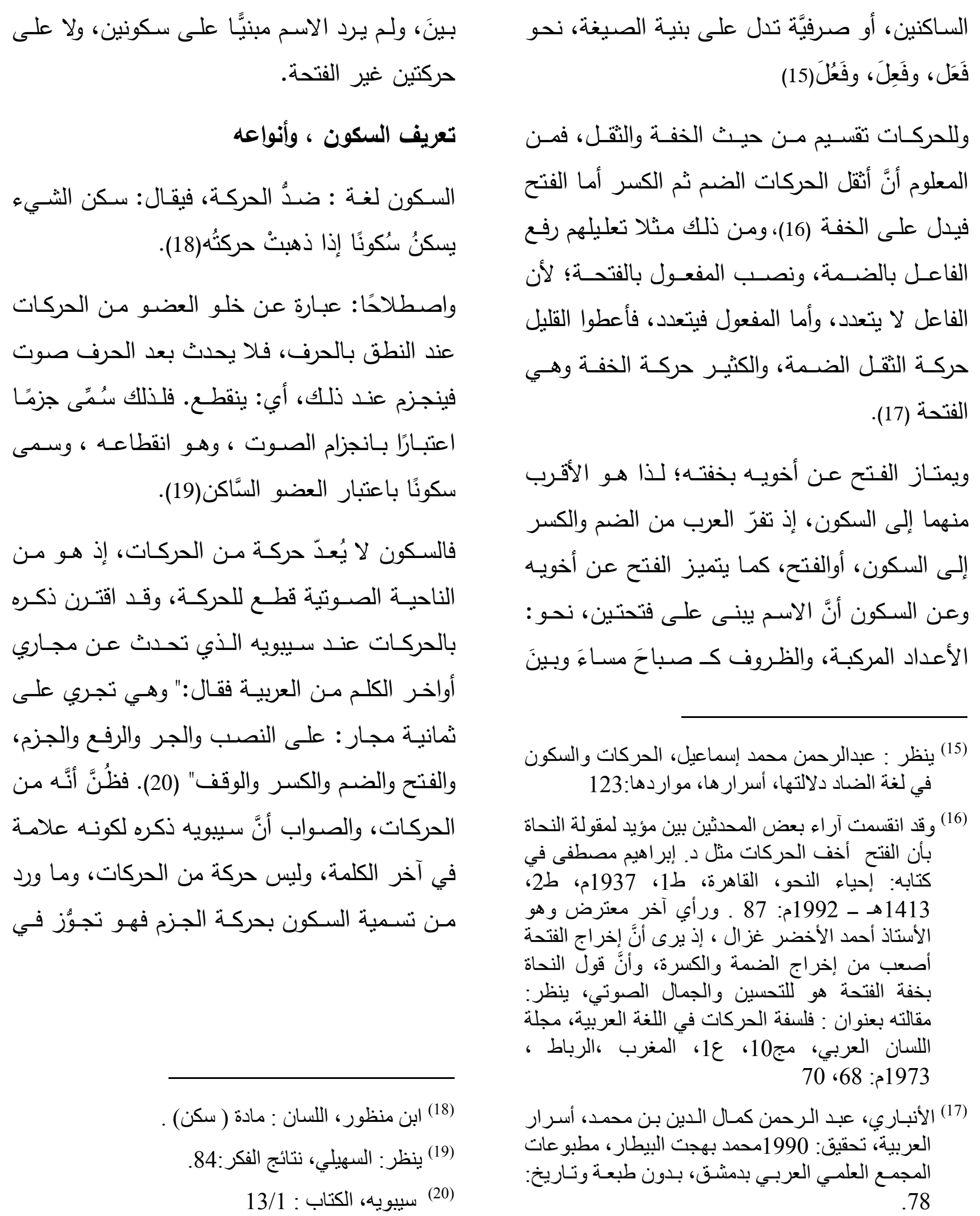


وهذا أحد ملامـح التقارب التي أجملْتُ ذكرها سابقا، وإليكم التفصيل: أولاً: وقوعهما للتخفيف: يفيدان التخفيف في المواضع الآتية: أ. وقوعهما في المعريات:

من المعلوم أنَّ الفتحـة تكون إعْرَابًا في نوعين

$$
\text { من أنواع الكلمة وهما: }
$$

ـ الاسم: تدل الفتحة على النصب في الفضـلات في المفاعيل، والحال والتمبيز والاستثناء، والاسم المفرد

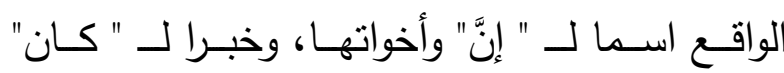

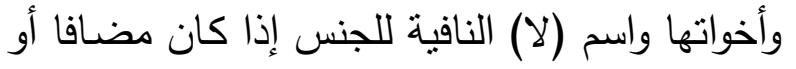
شبيها بالمضاف، وكذلك المنادى المضاف والثبيه بالمضـاف والنكـرة غيـر المقصـودة، وتكـون حركـة ولئ نائبة عن الكسرة في حال الجر في الاسم الممنوع من الصرف ، نحو : مررثُ بأحمدَ وإبراهيَ . ـ ـ والفعل المُضارع الذي لم يُسند إلى ألف الاثثين أو

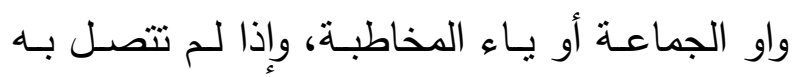

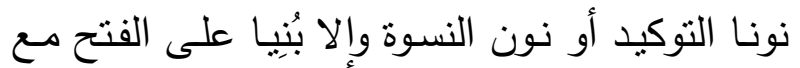

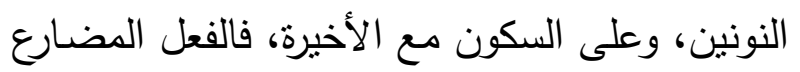

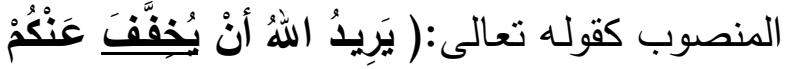

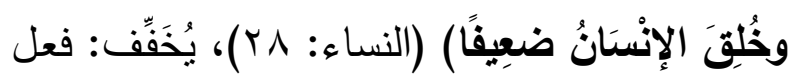
مضـارع منصسوب بأنْ وعلامـة نصبه الفتحـة، وإنَّما

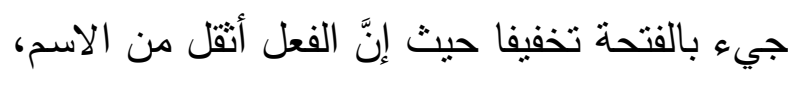
بعض الجو انب وخالفهم في جو انب أخر، بنظر: دراسات في علم اللغة : 194 فما بعدها.
التعبيـر ، وقد يُعلل لذكره مـع الحركات؛ لاشـتراكه

معها في الوظائف النحويَّة والصرفيَّة (21).

وللسكون أنواع باعتبارات، فباعتبار الأصسالة، ينقسم

إلى قسمين:

ـ سكون أصلي: وهو الذي جاء في المبنيات،. - وسـكون عـارض: كمـا فـي الوقف على آخـر المتحرك للتخفيف.

ومن حيث اعتباره من علامات أواخر الكلمة،

$$
\text { فيقسم إلى قسمين: }
$$

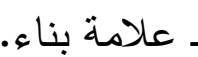

ـ وعلامة إعراب في جزم الفعل المضارع.

وللسكون أهمية لا تقل عن أهمية الحركات، فهو الملاذ حين تستتقل الحركات على الحرف ، فيُلْجَأ إليه لغرض التخفيف، فيقال في: عُنُق وإِِِل، مثناً:

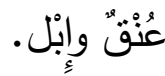
وظـاهرة التخفيف يثـترك فيها السكون مـع الفتح، ولكن هذه الخفـة تبدو أكبر في السكون منها في الفتح (22)؛ كونه ضد هد الحركة.

21) ينظر : د. كمال بشر ، دراسات في علم اللغة، دار

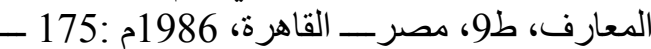
214

(22) خلافا لما ذهب إليه إبر اهيم مصطفى بأنَّ الفتح أخف من ون وناء

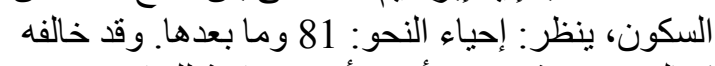
كمال محمد بشر في رأيه، و أبدى مو افقة للقدامى في الحي 


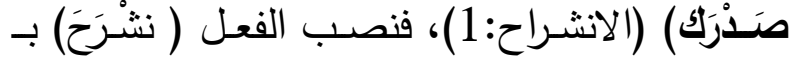

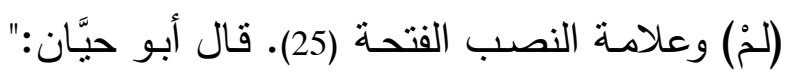

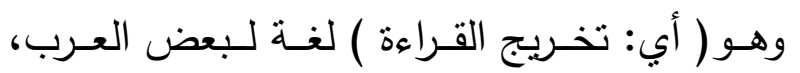

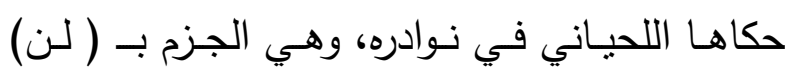

$$
\begin{aligned}
& \text { والنصب بـ ( لم) عكس المعروف عند الناس" (26). }
\end{aligned}
$$

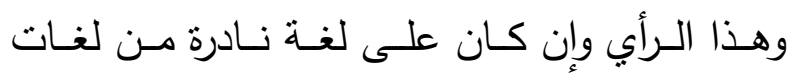

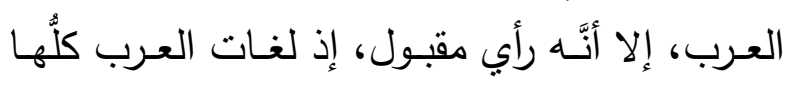

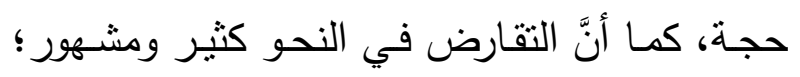

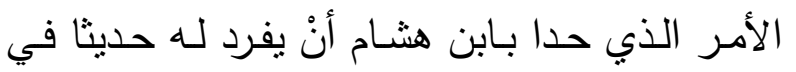

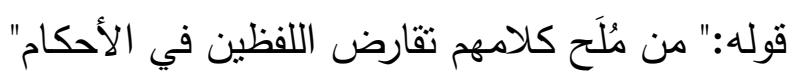

$$
\begin{aligned}
& \text { (27). وهذا الوجه أحد التخريجات في الآية (28). } \\
& \text { وقد يقول قائل: إنَّ الفتح جاء لطلب حرف الحلق }
\end{aligned}
$$

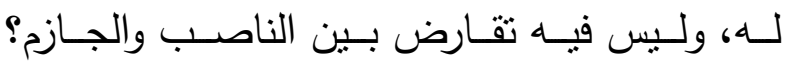

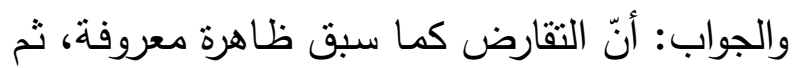

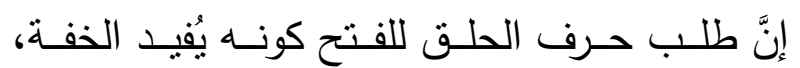

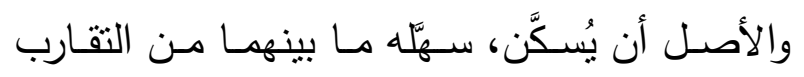

$$
\begin{aligned}
& \text { والتآخي. } \\
& \text { محي الدين عبد الحميد، ، مطبعة المدني ، القاهرة ، }
\end{aligned}
$$

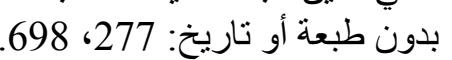

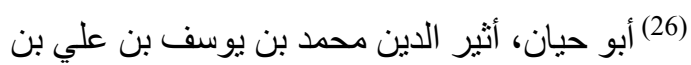

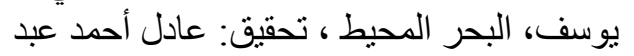

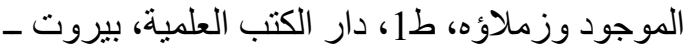

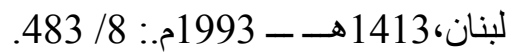

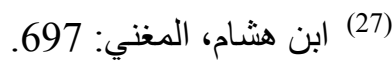

$$
\begin{aligned}
& \text { (28) ينظر : تخريجات الآية، ابن هشام، المغني: } 277 \text { ابن المغنا: }
\end{aligned}
$$




$$
\text { وقد جاء السكون في المواضع الآتية: }
$$

ـ في الحروف وهو كثنر فيها مثل: لُْ ولنْ وإنْ أنْ

$$
\text { إلى غير ذلك في الك }
$$

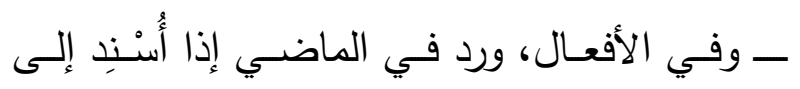

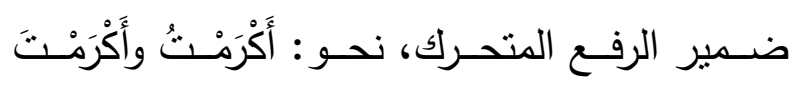

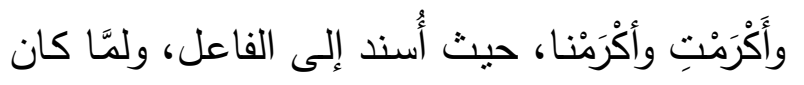

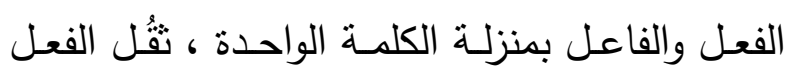

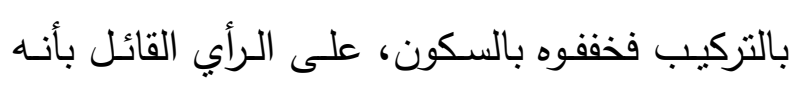

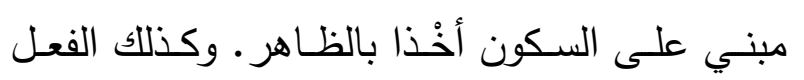

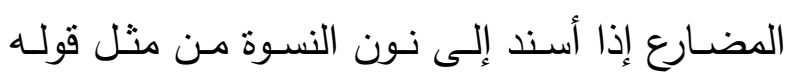

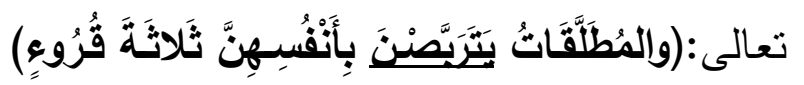

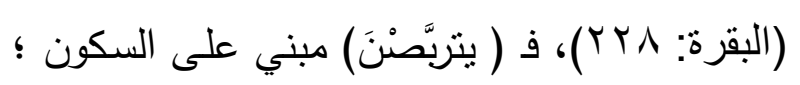

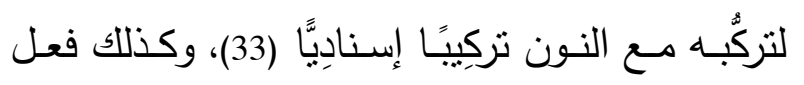

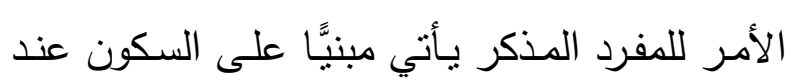

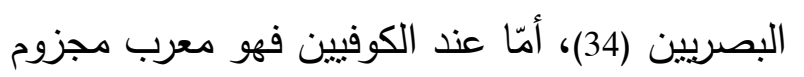

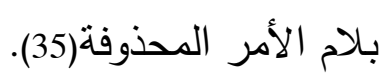

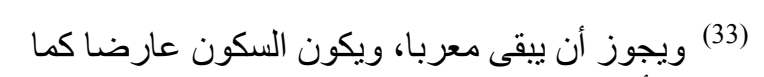

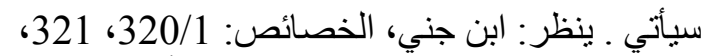

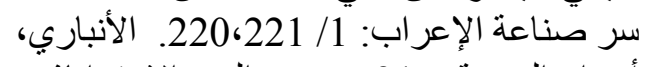

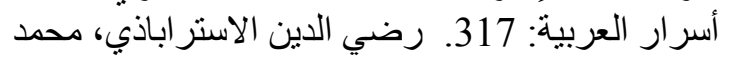

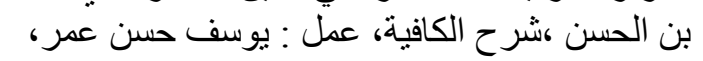

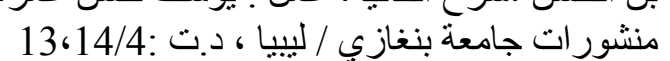

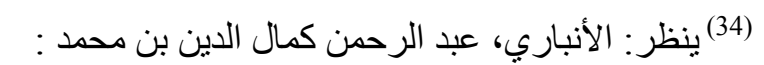

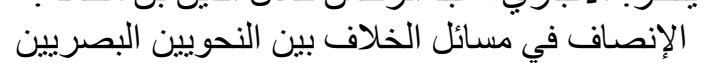

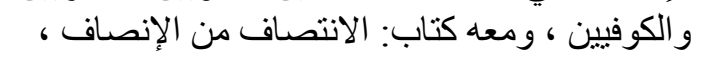

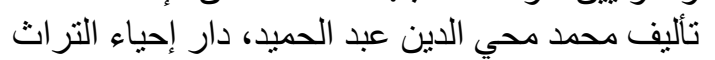
العربي، بدون طبعة وتاريخ: 2524.

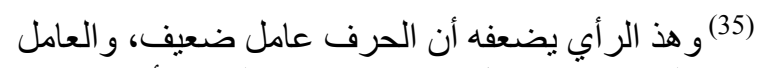
الضعيف لا يعمل محذوفا، ينظر : الفر اء، أبو زكريا
ومثال الجزم بـ (لنْ) قول الثاعر(29) :

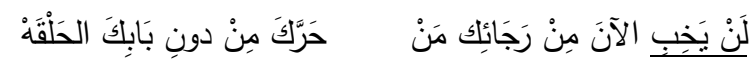
فجزم الفعل (يخِبْ) بـ (لنْ) وعلامة الجزم السكون.

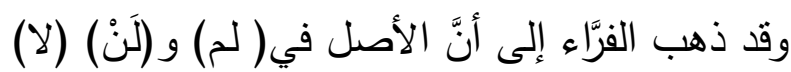

3ـ إثبات أحرف العلة في المضـارع المُعتل الآخر

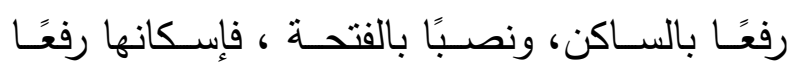

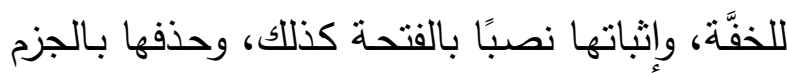

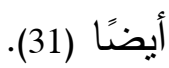

\section{ب - وقوعهما في المبنيات}

الأصـل في البنـاء السكون؛ لخفته، واستصـحابًا

للأصل وهو عدم الحركة (32)، يقول ابن مالك:

والأصل في المبنيِّ أن يُسَكَّا

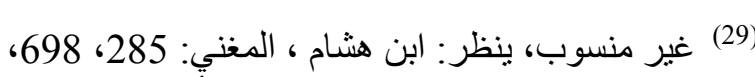

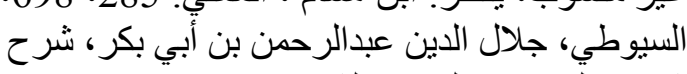

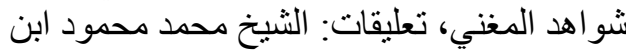

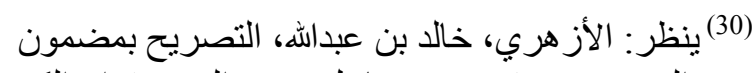

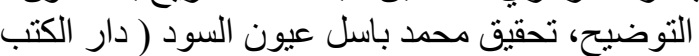

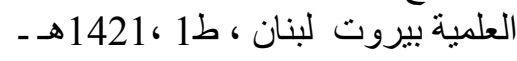
398/2:2000

(31) ينظر : الأزهري، التصريح: 86/1 ومابعدها.

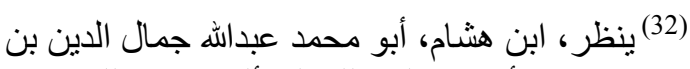

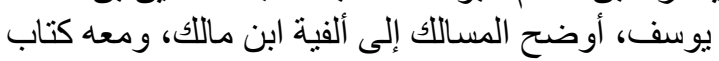

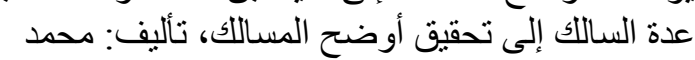

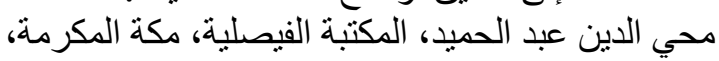
بدون طبعة أو تاريخ: 38/1 ـ الأزهري، النصريح: 
الأول معـرب إعـراب المثتى، والتناني مبني على

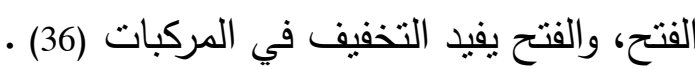

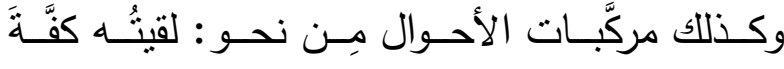

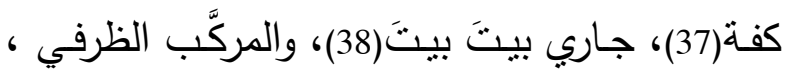

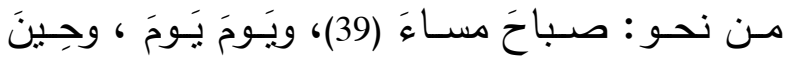
حِينَ. كما جاءت في الضمائر كضمائر المخاطب لَّب

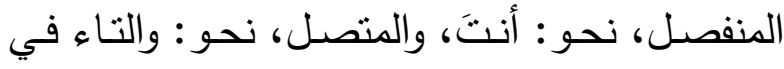

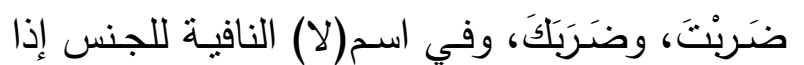
كان مفردًا، نحو : لا رجُلَ في الدَّارَ، وابنَ عمَّ وابنَ أمَّ في باب النداء. حيث ركب الجزآن تركيب خمسة عشر

فنتيَّن ممَّا سبق أنَّ الفتح والسكون يشتركان في: ـ وقوعهــا للبنـاء في أنـواع الكلم الثلاتـة الحرف والفعل والاسم - ـ - إفادتهما الخفَّة.

(36) ينظر : الرضي، شرح الكافية 3 / 135

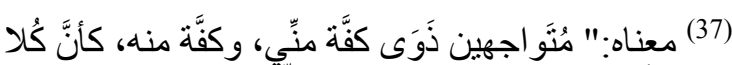

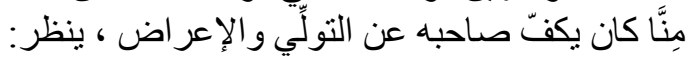

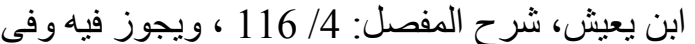
مركبات الأحوال أن يُضاف الصدر إلى العجز ، ينظر : الرضي، شرح الكافية 3 / 142 (38) ينظر: ابن يعيش، شرح المفصل: 14/ 117، والرضي،

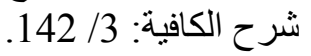

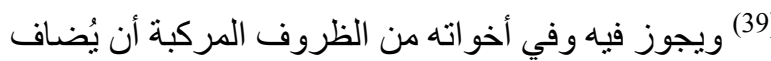

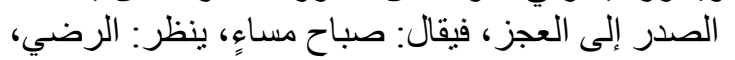

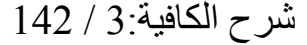

ــ في الأسماء، مثنل: كمْ الخبريَّة، و الاستقهاميَّة، ومَنْ الاستفهامية والموصولة.

ومثثله الفتح، إذ إنَّه ورد في أنواع الكلم الثناث في

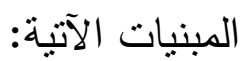

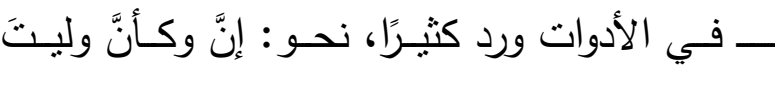

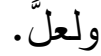

ـ ويأني في الأفعال، في الماضـي المسند للمفرد المذكر ، نحو : ذَهَبَ، والمضـارع المسند إلىى المفرد

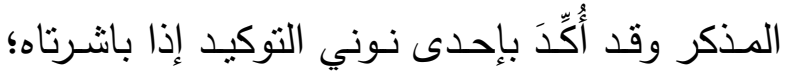

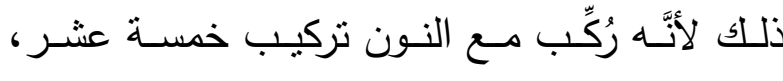

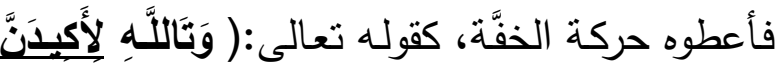

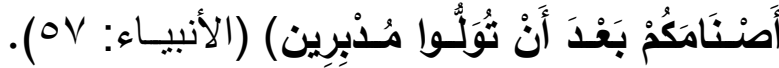
وكذللك فعل الأمـر المسـند للمفرد المـذكر إذا أسـند

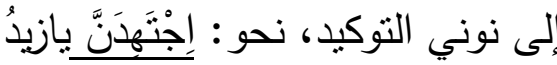

ـ وورد في الأسماء بسبطة كانت مثل: أبنَ، كيفَ

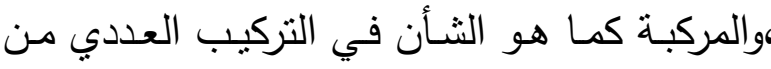

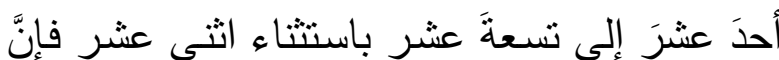

\footnotetext{
يحي بن زياد، معاني القرآن، تحقيق : أحمد نجاتى آلقي

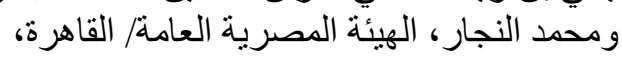

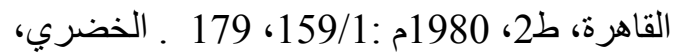
محمد الثافعي، حاثية الخضري على شرئ الثرح ابن عقيل

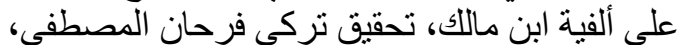

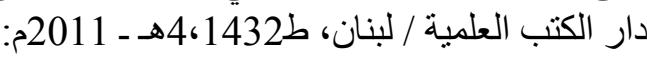
61 ، 60/1 
المســألة الأولـى :السـكون ومواطنـه،، وذلـك في

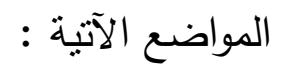

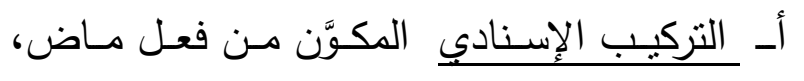

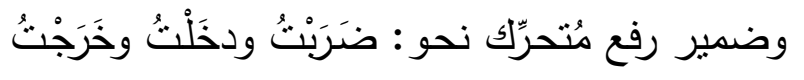
( على الرأي القائل ببنائه على الفتح)، والفعل المضارع

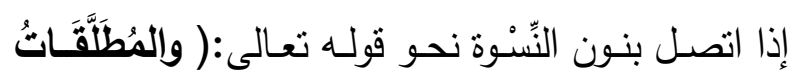

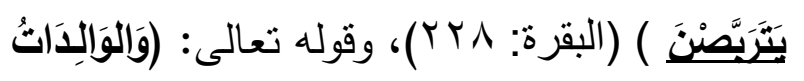

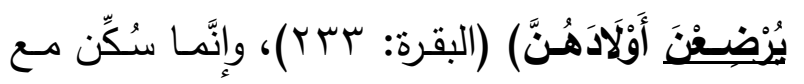

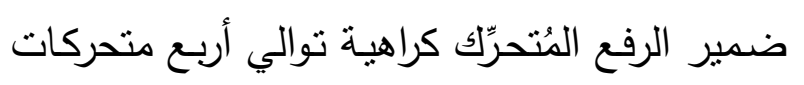

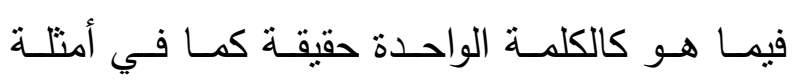

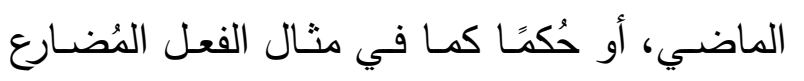

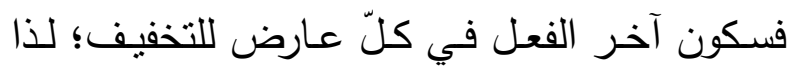
ذهـب بعضـهم إلى أنَّ الماضـي مبنـي على الفتح

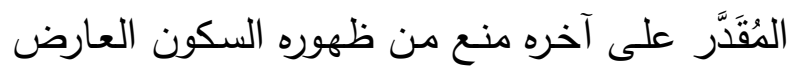

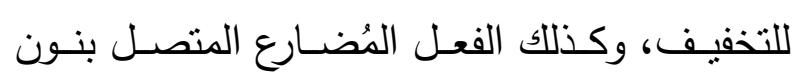

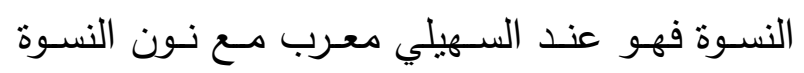

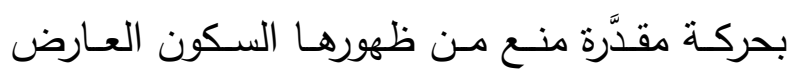
للتخفيف (43). قـال ابـن جنـي:" فمِيَّـا استندلَّ بـهـ ــ أي أبـو علـي

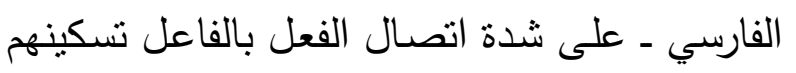

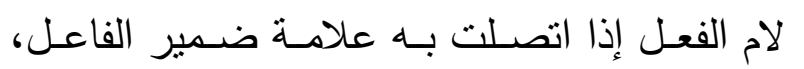

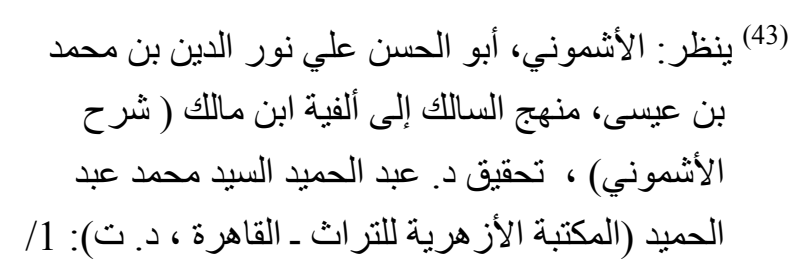

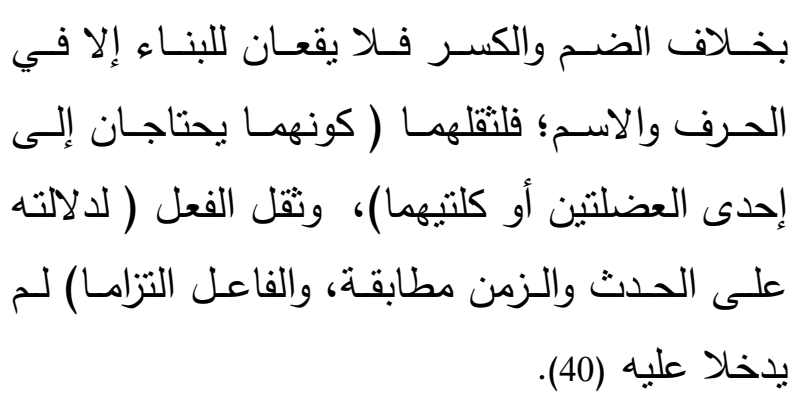

ج - وقوعهما على غير إعراب ولا بناء.

عُرِفِ عـن العـرب أنَّها نسـتنقل تـوالي الأمثنال

سواء أكان ذلك في الحركات أم في حروف المعاني

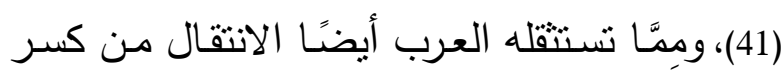

إلـى ضــم والعكس (42). وكـذلك نـراهم بسـنتقلون

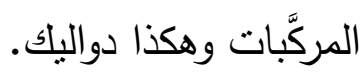

والحديث عن ذلك يأني في مسألنتن:

(40) ينظر : الأزهري، التصريح:54/1. ويقول الفراء:" فإنَّما

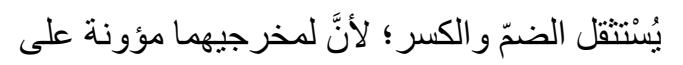

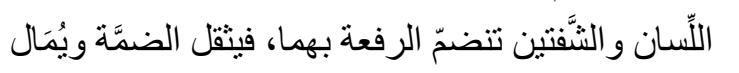

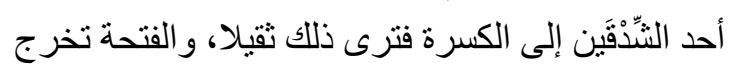

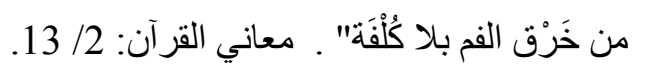

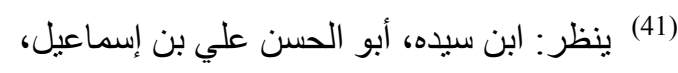

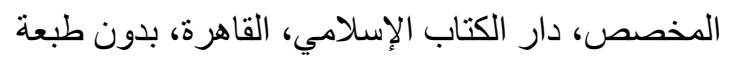

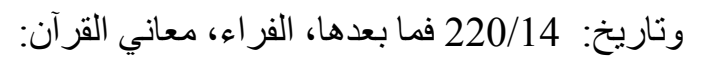

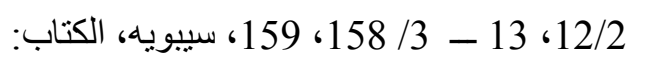

$289 ، 198 / 4$

(42) ينظر: ابن جني، سر الصِّناعة: 18، 22، 773، 816 


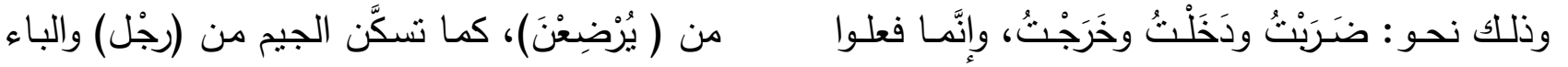

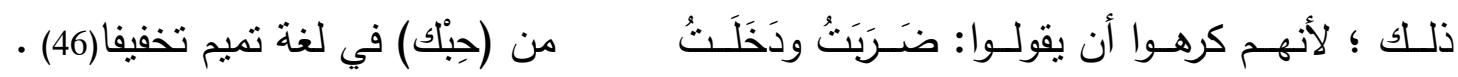

ب - الإثـارة إلى لغـة بعض العرب كلغة تميم في تسكين كل ثنلاثي مضموم العين ومكسورها تخفيفًا، وهذا التسكين جائز لا لازم بخلافه في ( ضَرَبْتُُ) ونظائره، سواء أكان ذلك الثلاثي اسمًا نحو : رَجُّل

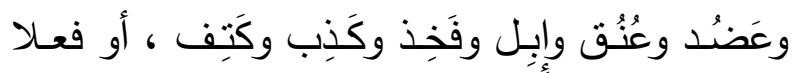

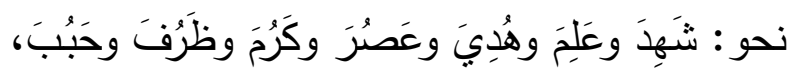

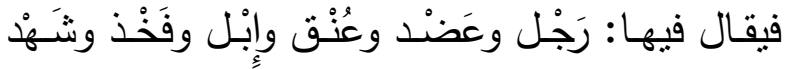

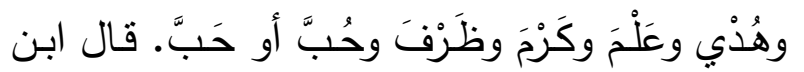

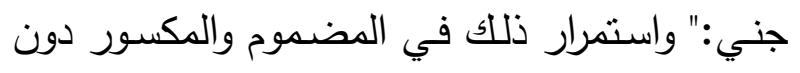

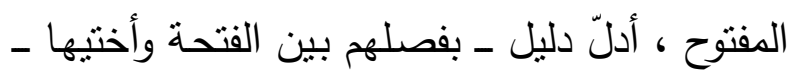
على ذوقهم الحركات، واستثقالهم بعضها واستخفافهر الآخر، فهل هذا ونحوه إلا لإنعامهم النَّظر في هذا ولها القدر اليسير المُحتقر من الأصوات، فكيف بما فوقه من الحروف التوامّ، بل الكلمة من جملة الكلام" (47) ومن هذا الوادي ( المَتُّلَات) في قوله تعالى: ( وَقََْْ

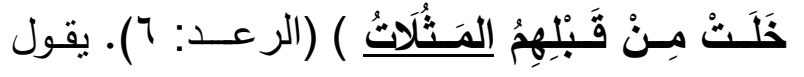
الفرَّاء:" وهم يَرَون العقُوبات المَتُّلات في غيرهم مِمَّن

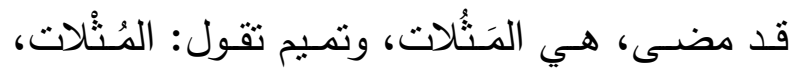

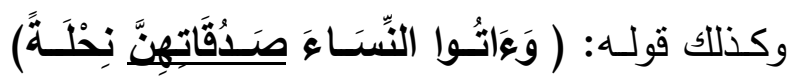

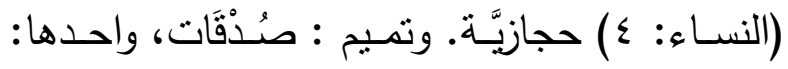

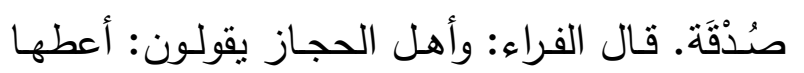

(46) ينظر : ابن سيده ، المخصص: 220/14. (47) الخصائص: 75/1، بنظر : ابن جني، المحتسب:53/1 وخَرَجَتُ؛ لتوالي أربعة متحركات ، فلولا أَنَّهم قد نزَّلَُوا

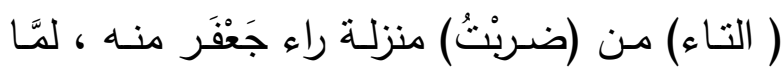

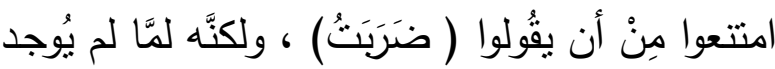

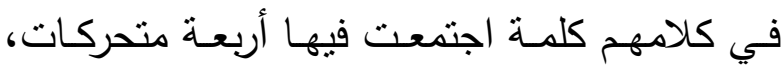
ونُزَّلَتَ ( التاء) من ( فَعَلْتُ) منزلة الجزء من الفعل،

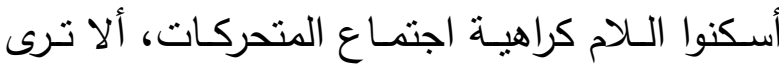
أنَّهم لا يكرهون هذا التوالي إذا اتصل الفعل بضمير

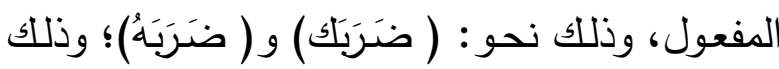

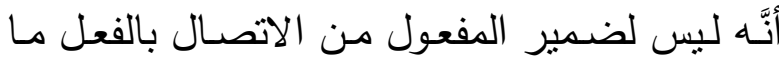

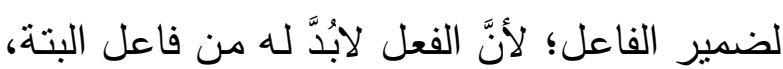
وقد يستغني عن المفعول في كثير من أحكامه" (44)

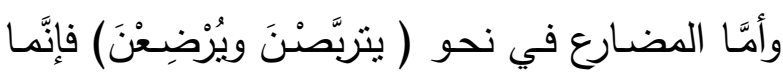
سكَّن آخره حملا على الماضِي في ضَرَبْنَ وخَرَجْنَ (45) - (45) ـ هذا تعليل النحاة. وعندي وجـه آخر وهو أنَّهم أجْرَوا ( بَصْنَ) مـن

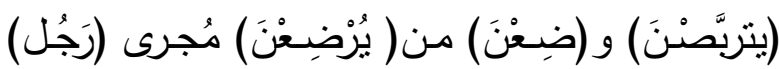

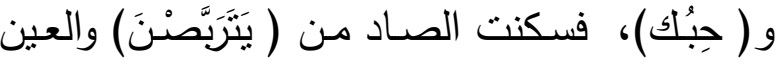

(44) ابن جني، سر الصناعة: 1 / 220 ، 321 ، 221 ، وينظر : ابن

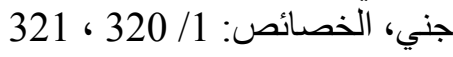

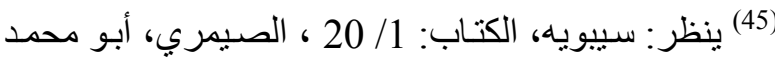

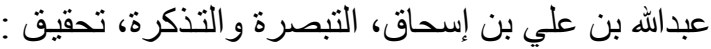

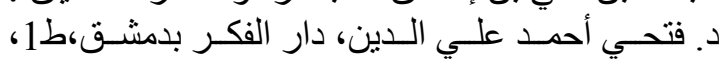

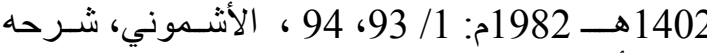

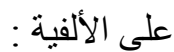




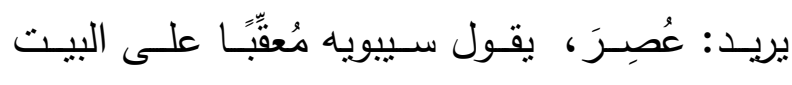

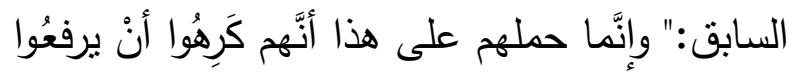

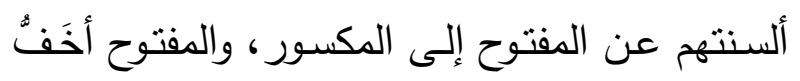

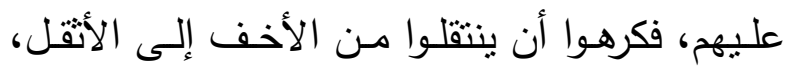

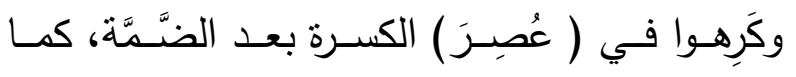
يكرهون الواو مـع الياء في مواضـع ، ومـع هذا أنَّهـ

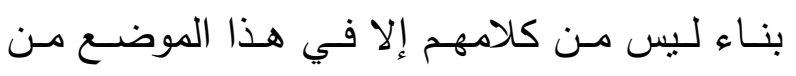

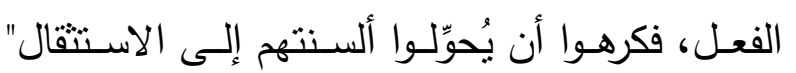

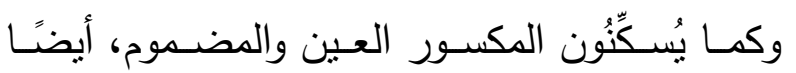
يسكنون ماتتابعت فيه ضمنان، نحو : طُنُب ورُسُّل

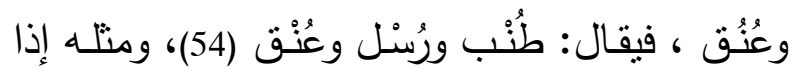
تتابعت الكسرتان ، كقول الراجز (55):

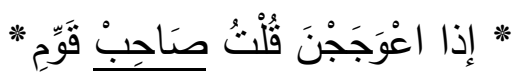
يريدـ: صـاحِبِ • يقول سيبويه:" وكذللك الكسـرتان

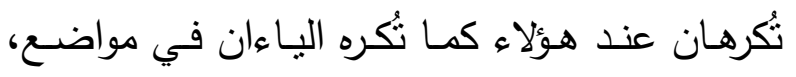
وإنَّما الكسرة من الياء، فكرهوا الكسرتين كمـا تُكره الياءان، وذلك في قولك في إِِل: إِبْلُ " (56)

114/4 الكتاب: (54) ينظر : سييويه، الكتاب: 1/2/ 114، الفراء، معاني القرآ: .13 ، $12 / 2$ (55) بلا نسبة عند سييويه، الكتاب: 203/4، الفر اء، معاني القرآن:12/2، ابن جني، الخصائص: 75/1

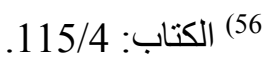

صَدُقتها، وتميم تقول: أعطها صُدْقتها في لغة تميح" ومتلك نسكين الباء في قول امرئ القيس:

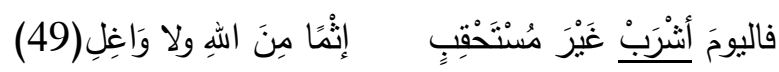

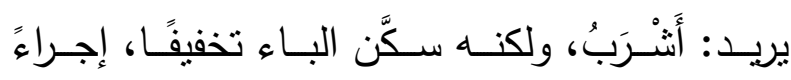
للمنفصل مُجرى المتصل، يقول ابـن جني:" كأنَّهُ

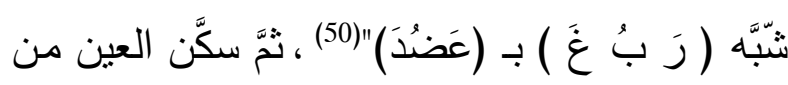
الثلاثي على لغة تميم كما مر سابقا وتنكين الفاء

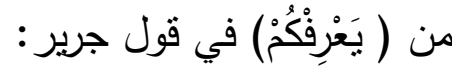

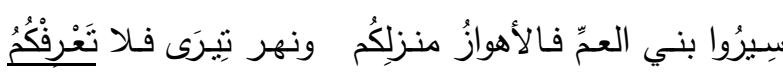
العربُ (51).

يريد : فـلا تعرفُكُم ، ولكنَّه سكَّن للتخفيف كما هي لغة قبيلته تميم. لغدان

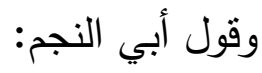

* لَوْ عُصْرَ منهُ البانُ والمِنْكُ انْعَصَرْ * (52).

59/2 (48) معاني القر آن (49)

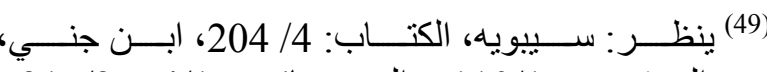

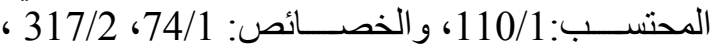
$96 / 3$ ، 340

(50) (50/3) الخصائص، 96/30

(51) ينظـر، ابـن جنـي، المحتسـب: 110/1، 110/2، الخصــائص:

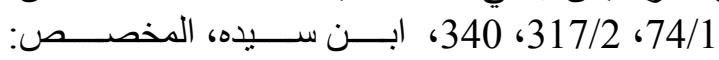
$.188 / 15$

(52) ينظر : سييويه ، الكتاب: 114/4، ابن سيده، المخصص: ،220/14 
والوقف في كلام العرب لله أوجه متعددة (62) منها : • السئكون

والعرب تقف على المُحرَّكَ بالسُّكون رفعَا وجـرا،

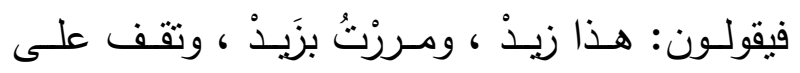

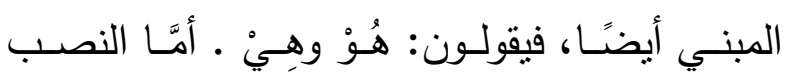

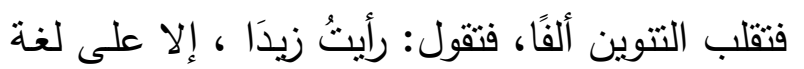

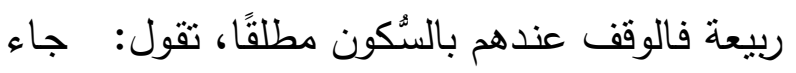
زيذّ، ورأيتُ زيذْ، ومرزْتُ بزيدْ.

وثَمَّة وقف بنقل حركة الحرف إلى ماقبله بشروطه

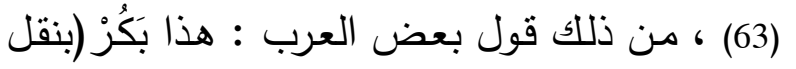

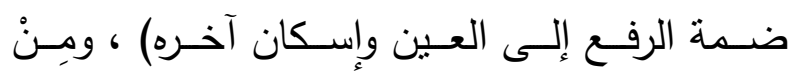
بكِزْ (بنقل كسرة الإعراب إلى العين وإسكان آخره)،

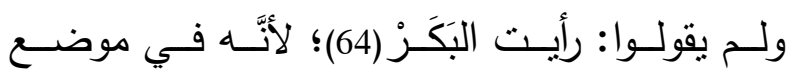
التتوين(65) ، ولأنَّ الفتح خفيف، والخفيف لا يُخَفَّف. ومن ذللك قول الثاعر :

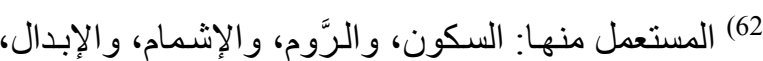

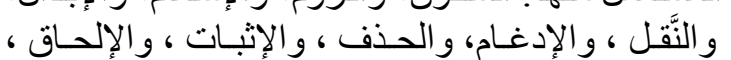
ينظر: ابن الجزري، النشر في القراءات العشر:الترائ 120

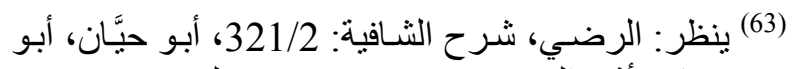

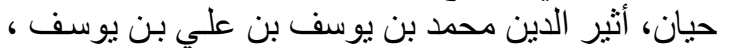

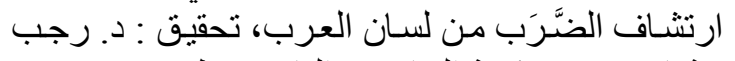

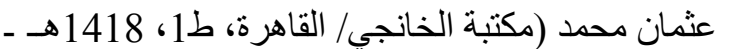
1998م ) (64) ينظر : سييويه، الكتاب: 173 / 173 (65)

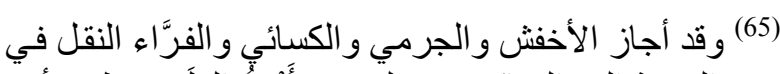

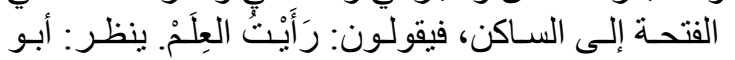
حبان، الارتنشاف:
هـذا حـال الضــمَّنين والكسـرتين، ولكـن ماحـال الفتحتين إذا توالتا أتخففان أم لا؟ فالجواب: إنَّ الثقل الحاصل من الضم والكسر جعل بعض العرب يميلون للتخفيف بالتسكين ، كما مُثنّل،

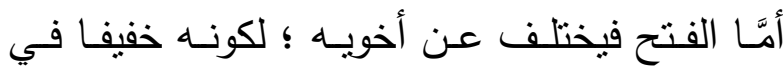
الأصل، وللتقارب الكبير بينه وبين السكون؛ لذا لم يُسَكَنِّوه، فقالوا: جَمَلّْ، وحَمَلْ (57). ج - السكون لأجل الوقف

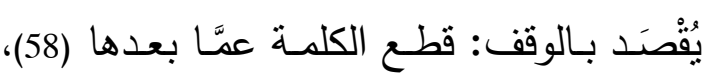

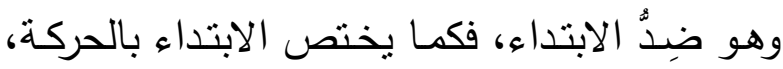

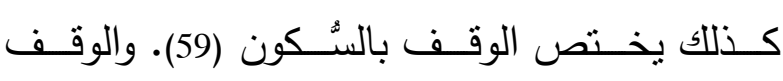

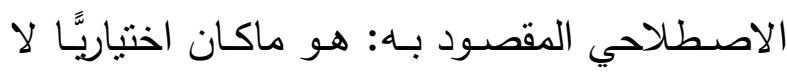

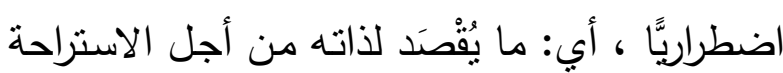

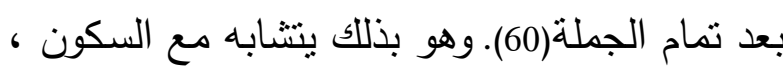

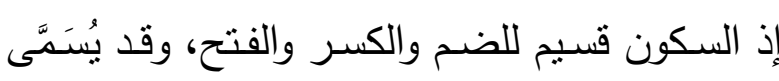
الوقف (61) - الون

115/4 وينظر سيبويه الكتاب:

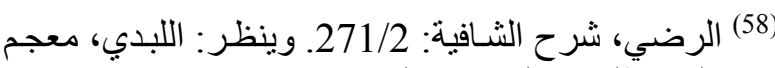
المصطلحات النحوية والصرفية: 245.

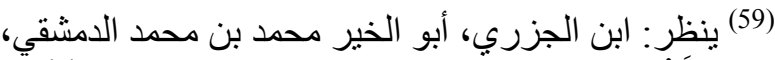

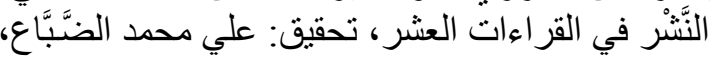

دار الكتاب العربي، بدون طبعة وتاريخ:121/2 (60) اللبدي، معجم المصطلحات النحوية والصرفية: 245.

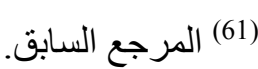


يُعدّ الفتتح أخفـ الحركات؛ لذا يمنـع سـيبويه

تسكين الفتح (70)، وقد جاء في غير إعراب وبناء

$$
\text { في المواضع الآتية منها: }
$$

أ - التخلص من التقاء الساكنين اللذين أولهما ياء،

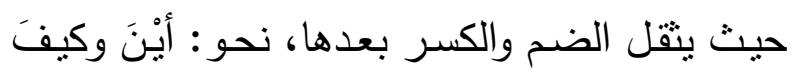

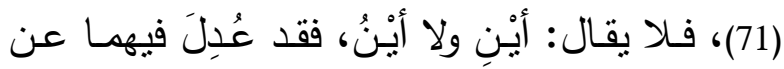
السكون إلى الحركة ؛ للتخلص من التقاء الساكنين،

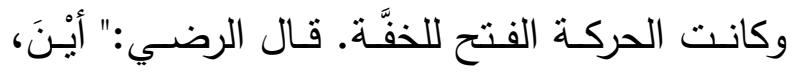

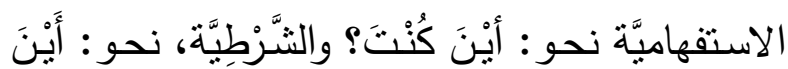

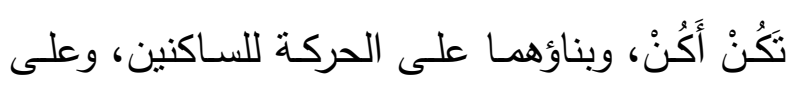
الفتح؛ لاستثقال الضم والكسر بعد الياء" (72). ب - كراهيّة توالي الأمثال، كما في بـاب النسب إلى الثنلاثي المكسور عينه، يقول الرضي:" اعلم أنَّ المنسوب إليهه إذا كان على ثناثة أحرف أوسطها مكسور وجب فتحه في النسب، وذلك ثناثة أمثلة:

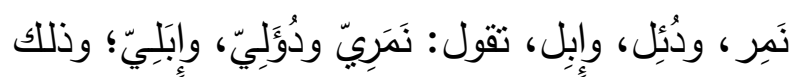
لأنك لو لم تقتحه لصار جميع حروف الكلمة المبنية

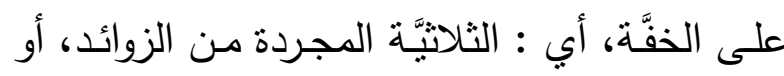

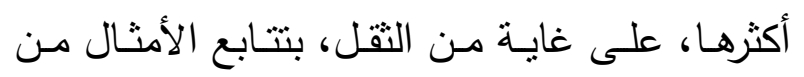

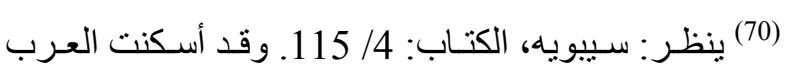
المفتوح في الضـرورة ، ينظر : ابـن جني، المحتسـب: المبرب: $56 / 1$

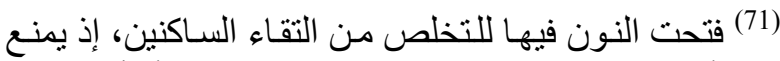

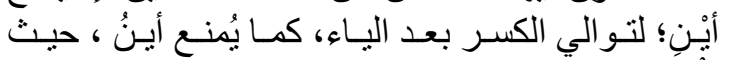

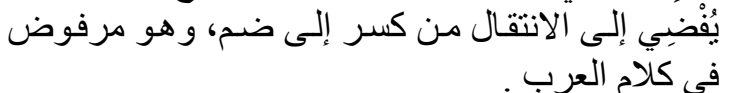
202/3. شر ح الكافية
* أنَا ابنُ ماوِيَّة إذ جَدَّ النَّقرُْْ (66) أي: النَّقرُ ، فنقل الضمَّة للحرف الذي قبله ، وسكَّن

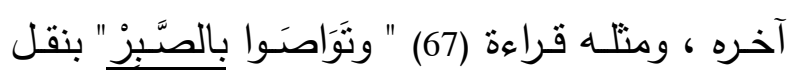

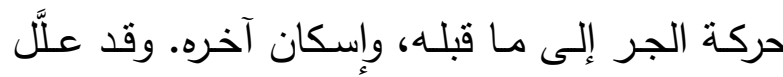
علماؤنا الوقف على السكون بأمرين(68):

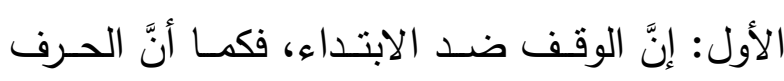
المبدوء به لايكون إلا متحركا، فكذلك الموقوف عليه لايكون إلا بضده وهو السكون.

الثناني: إنَّ الوقف موضــع اسـتراحة؛ لأنـهـ موضـع

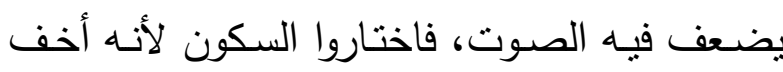
من الحركة (69).

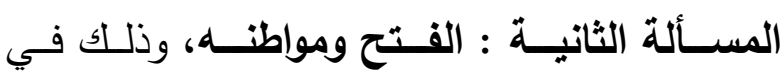

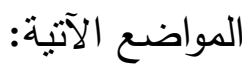

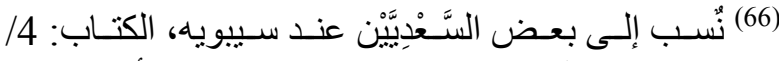

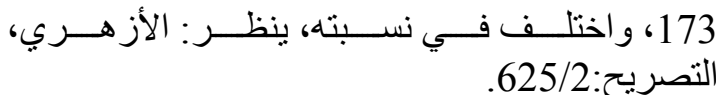

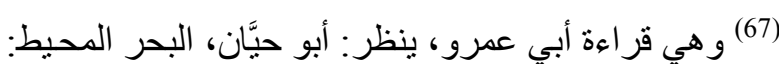
607/8، الأزهري، التصريح: 625/2.

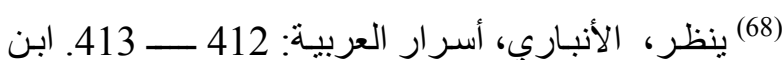
يعيش، شرح المفصل:67/9.

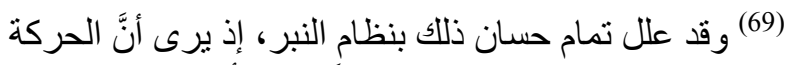

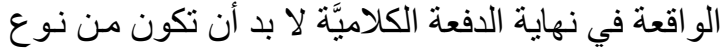

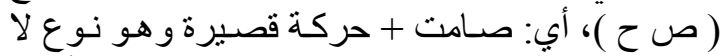

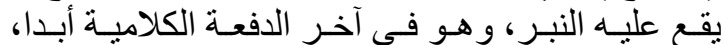

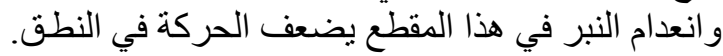

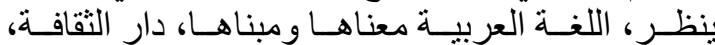

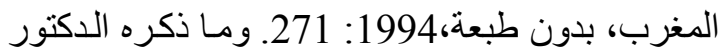
لا يختلف عن تعليل علمائنا . 
فــي قــولهم: ناصِيَّة ( نَاصنــاة)، وفــي جاريــة (جَارَاة)(77). ومن ذلك قول زيد الخيل الطائي: لعمرْكَ ماأخشى النَََّعْلُكَ مابقًا

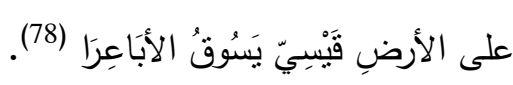

يعني: مـابِِيَ، ولكنَّه، فتح عين الفعل تخفيفا، ثم

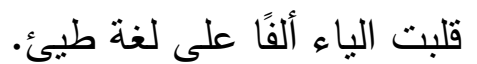

وثثَّة لغة أخرى تُسب لبني ضَبَّة الذين يفرُون من

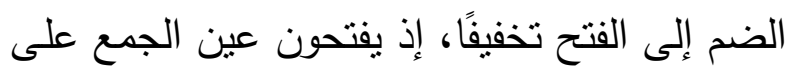

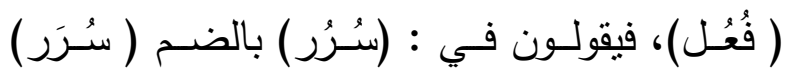
بالفتح، قال أبو زيد :" سمعت من بني ضَبَّبَّة سَرِيرُ و و

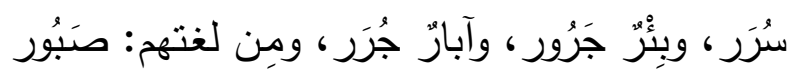
وصُبر ، يكرهون الضمَتَنَنِ"(79). فالجـامع بـين الفـتح والسـكون في هـــا الموضـع إفادتهما التخفيف.

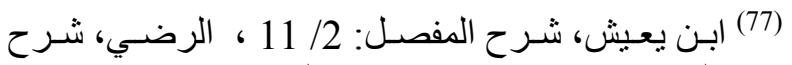

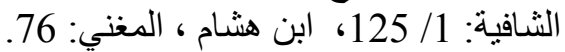

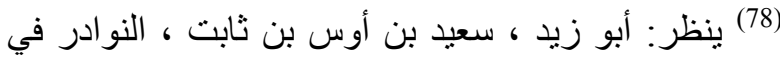
اللغة، تحقيق: محمد عبد القادر أحمد، دار الثراب ، الثروق في ؛

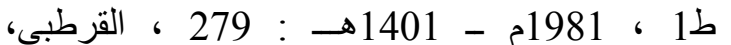
أبو عبداله محمد بن أحمد الأنصاري ، الجامع لأحكام

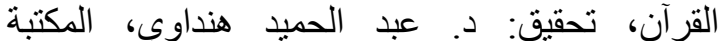

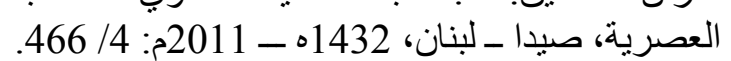

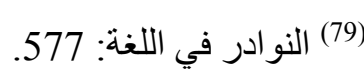

الياء والكسرة"(73)، وسواء أكان مكسور العين ثلاثئًا

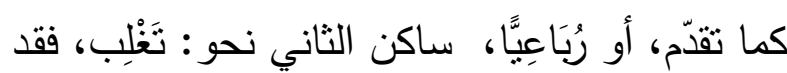
سُمِعِ فيه الفتح في عينه، فقالوا: تَغَظْبِّيّ (74). وكذللك النسب للاسم المنقوص، وياء المنقوص ثالثة، نحو:

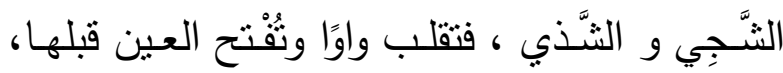

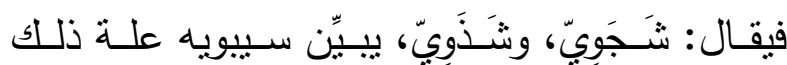

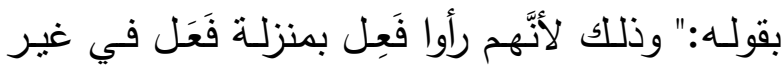

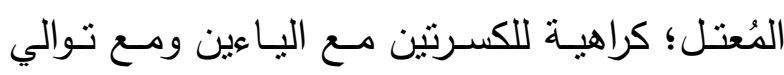

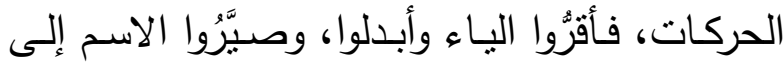

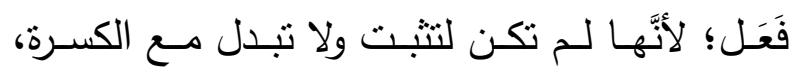
وأرادوا أن يَجري مجرى نظيره من غير المعتل" (75) ج - الإثـارة إلى لغة بعض العرب ومنهم طئ ،

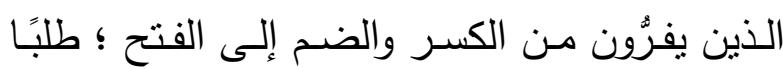

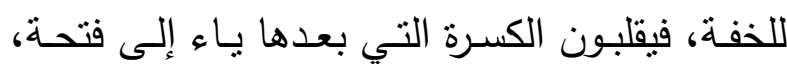
فتتُقلب الياء ألفا، وذلك في كل معتل سُبَتَت فيه الياء

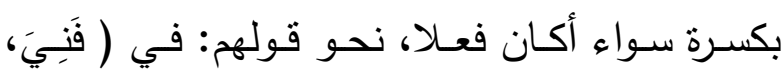

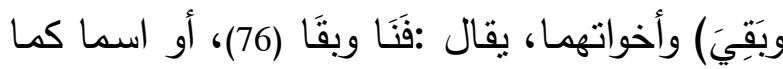
343. شـرح الثـافية: 18 ، و وينظر : سييويه، الكتـاب: 3/

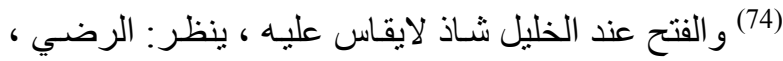

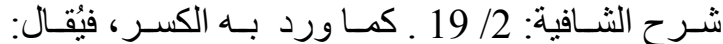

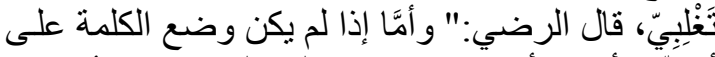

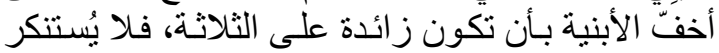

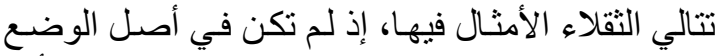

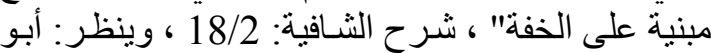

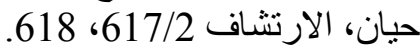

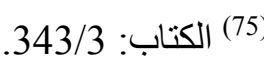

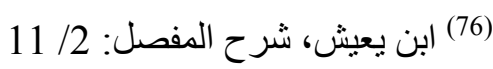




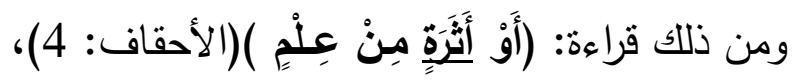

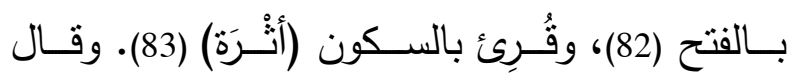

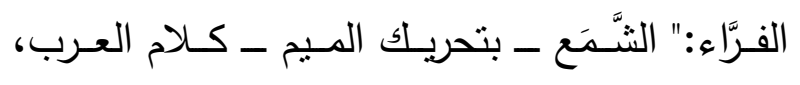
والمولدون يقولون: شَشْعَ" (84).

كما جاء التعاقب بينهما في المعتل، فيقال: (أَيْدِّ

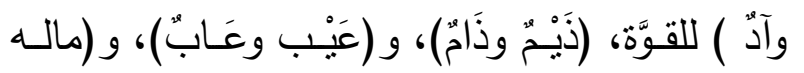

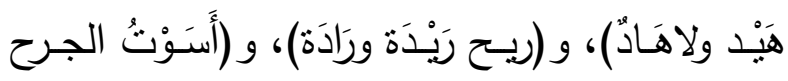

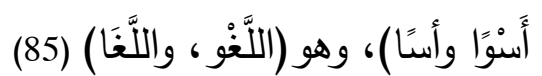
ب - تعاقبهما على ياء المتكلم إذ يجوز فيه الفتح

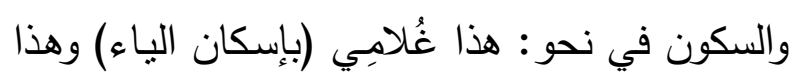

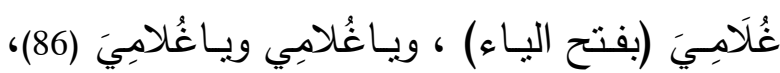

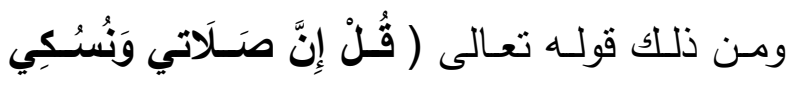

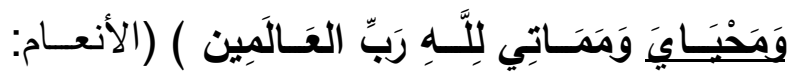
بآ1)، قرأ الجمهور بفتح ياء المتكلم وهو القياس لـاس في الاسم المعتل المضاف فيما كان آخره ألفا (87)،

(82) قر أ بها ابن عباس و عكرمـة وقتادة و عمرو بن ميمون

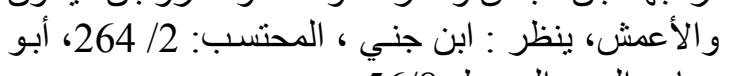
حيان، البحر المحيط:

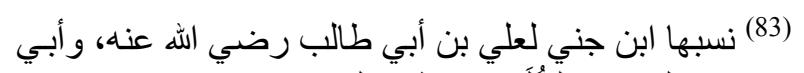

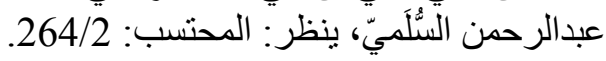
(84) ابن قتيبة، أبو محمد عبداله بن مسلم، أدب الكاتب، حققه:

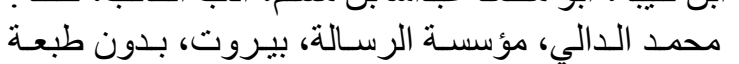

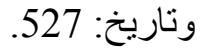
(85) (المصدر السابق.

(86) ينظر ، ابن يعيش، شرح المفصل: 32/ 32

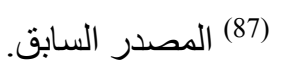

ثانيا: تعاقبهما على الموضع الواحد.

يتعاقب السكون والفتح على الموضع الواحد،

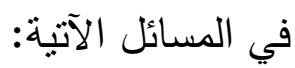

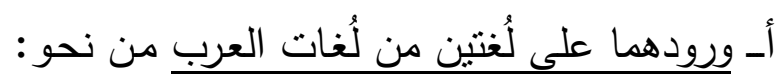

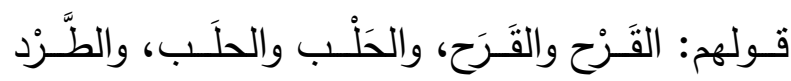

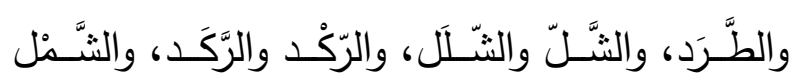

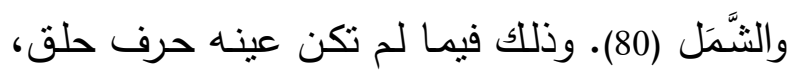

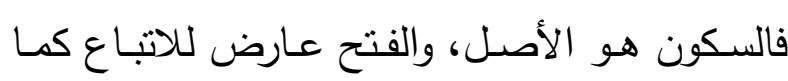
في: جَفَنَات وسَجَدَات، فإنْ كانت اللام حلقيَّة فتحت ماقبلها، نحو : نَفَعَ يَنْفَعُ، ولَجَأَ يَلْجَأ، وكذللك إنَ كانت

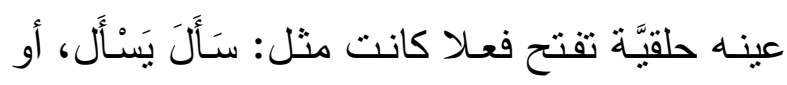

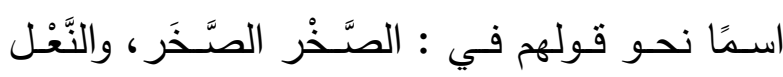
النَّعَل. قال ابن جني:" ولعمري إنَّ هذا عند أصحابنا ليس أمرًا راجعا إلى حرف الحلق، لكنها لغات، وأنا أرى في هـذا رأي البغـداديين في أنَّ حـرف الحلـق

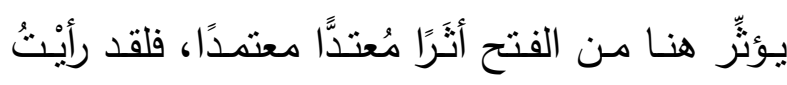
كثيرًا من عُفَتَل يُحرِّك من ذللك مالا يتحرك أبدًا لولا حرف الحلق، وهو قول بعضهه: نَحَوَه، يريد: نَحْوَه، وهذا مالا توَقُّف في أنه أمر راجع إلى حرف الحلق؛ لأنَّ الكلمة بُنِيت عليه ألبتة, ألا ترى أن لو كان هذا

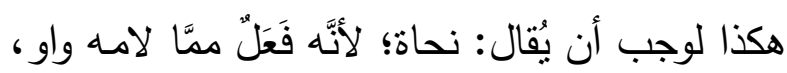
فيجري مجرى عصساة وفتاة. نعم، وسمعتُ الثـري يقول في بعض كلامه: أنا مَحَمُوم بفتح الحاء" (81). لينظر: ابن جني، المحتسب: 166/1. (81) 


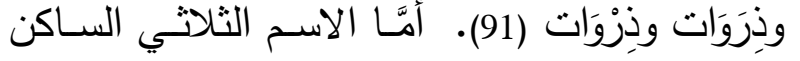

$$
\begin{aligned}
& \text { العين غير معتلة ولا مدغمة، }
\end{aligned}
$$

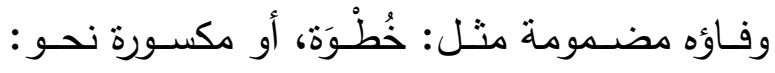

$$
\begin{aligned}
& \text { كِنْرَة ، فيجوز في العين الفتح والسكون، فيقال: }
\end{aligned}
$$

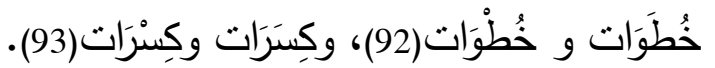

$$
\begin{aligned}
& \text { فالفتحة عارضة، والثُكون منويٌّ . }
\end{aligned}
$$

أمَّا إذا كانت العين معتلة، نحو : بَيْضَة ولَوْزَة وَعَوْرَة

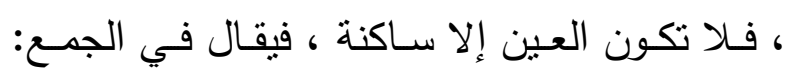

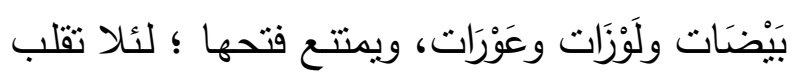
الواو والياء ألفًا لتحركهما، وانفتاح ماقبلهما، حتى فيلى

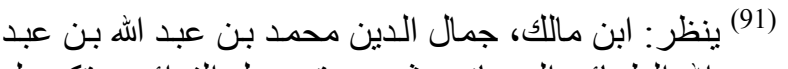

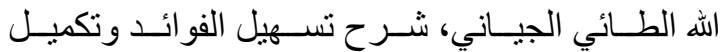
المقاصد ، تحقيق: محمد عبد القادر عطا وطارق فتحي

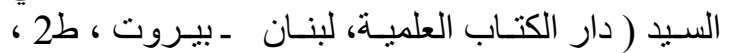

2009م : 102/1 ، الأزهري، التصريح:

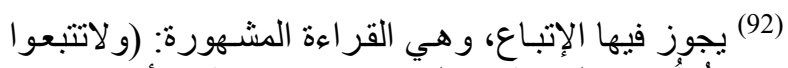

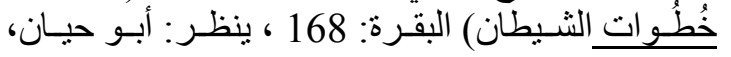

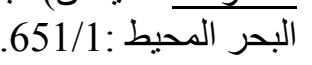
(93) بنظر: الأزهري، التصريح:
}

وقرأ نافع بإسكان الياء( ومَحَيَايْ)(88)، وهذه القراءة

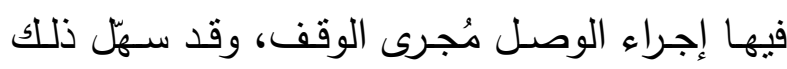

$$
\text { تقارب القتح والسكون وخفتهما. }
$$

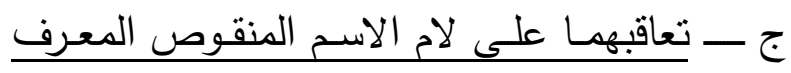

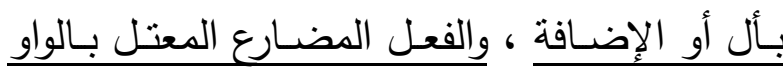

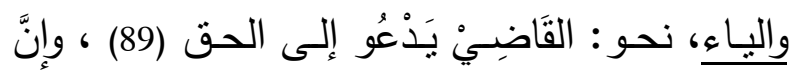

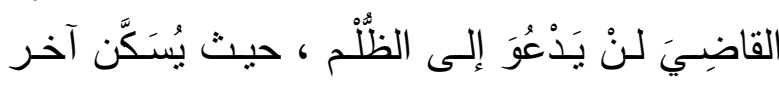

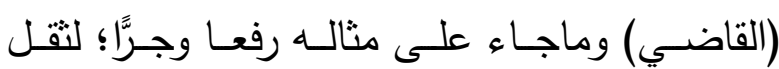

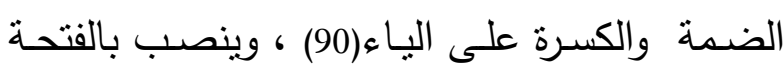
تخفيفا، وكذلك يدعو ويرمي وكل معتل ناقص بالواو والياء يسكن آخرها في الرفع، وينصب بالفتحة.

د - تعاقبهما على عين ماجمع بألف وتاء مزيدتين

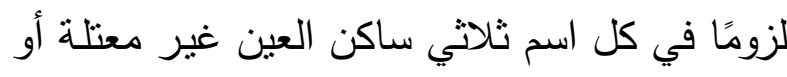

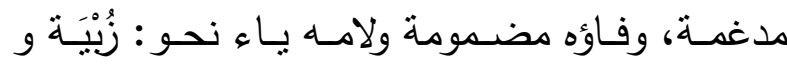

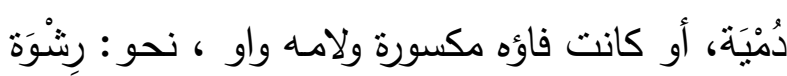

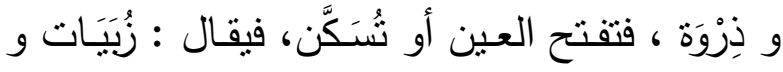

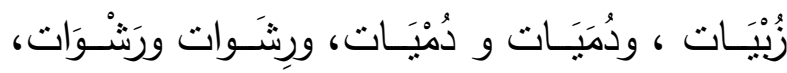

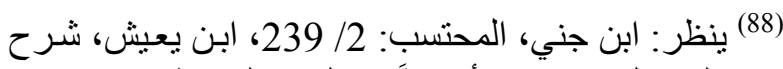

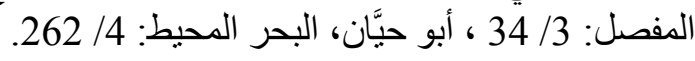

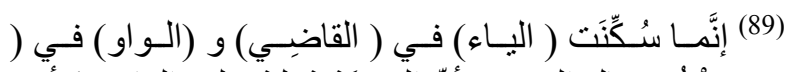

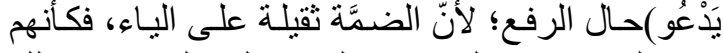

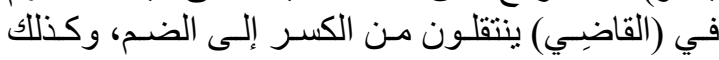

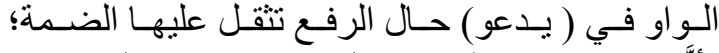

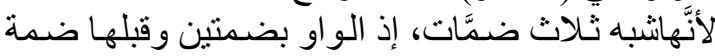

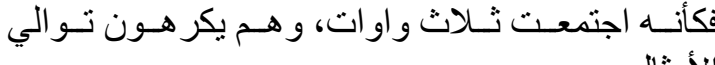
(90) ينظر : ابن يعيش، شرح الدفصل: 56/1 


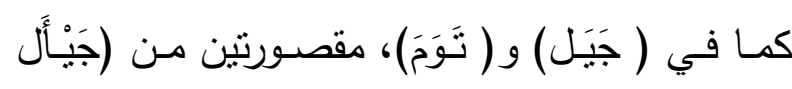
وتَوَأَم )، فالسكون فيهما منوِيّ والحركة عارضة. ثالثًا: التعادل بينهما في بعض الأحكام.

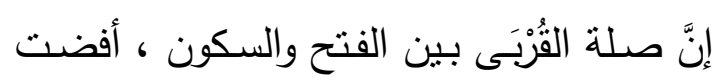
إلى تكافؤ بينهما في بعض الأحكام، ويتبيَن ذلك في

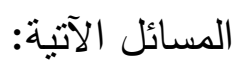

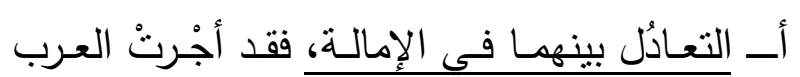

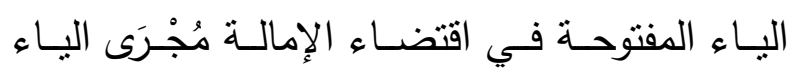

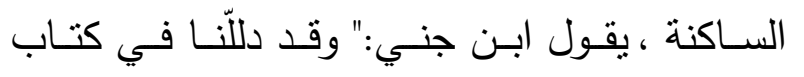
الخصائص(98) على تقاود الفتح والسكون؛ ولأنَّهما يكادان يجريان مجرى واحدا في عدة أماكن. منها

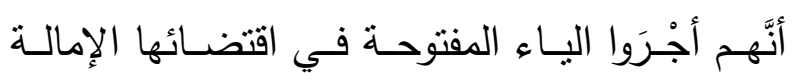

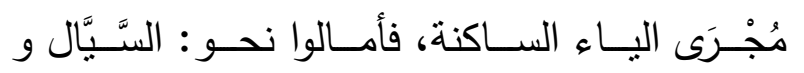

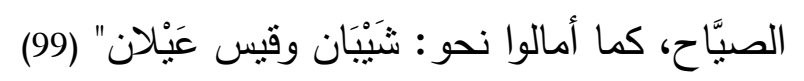

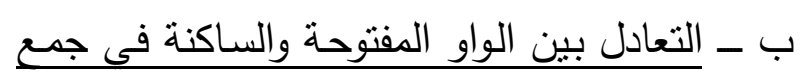

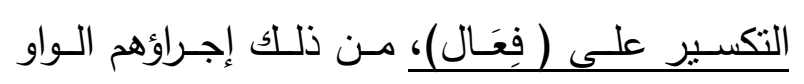

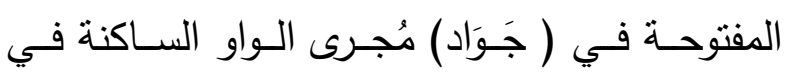

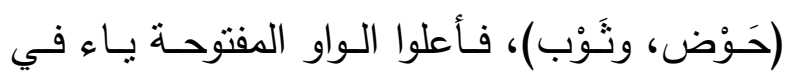

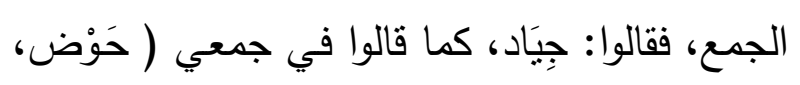

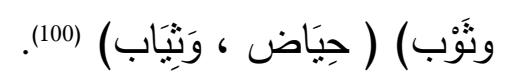

(98) ينظر : ابن جني، الخصائص: 19 / 59 ، 60

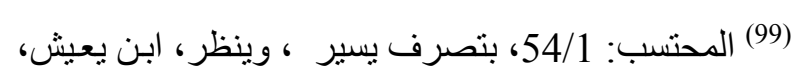
شرح المفصل: 56/9

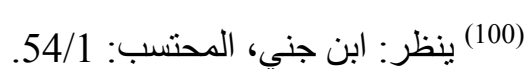

لايلتبس بها ماعينه ألف منقلبة ، نحو : قَارَة وفَارات، وحَارَة وحَارَات (94). غير أنَّ هُدنْيًا فتحت العين دون إعـلد، كما في قول الثاعر:

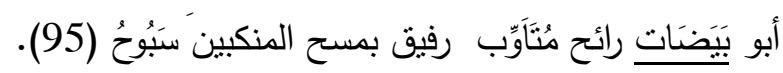
فقتح عين الثناتثي المعتلـة في الجمـع دون إعـلال

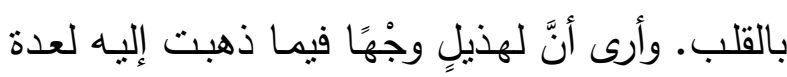
أمور : باب

الأول : ورود قراءة(96). بلغة هُذِيل في قوله تعالى:

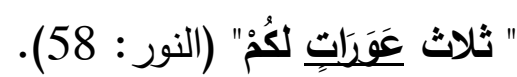

الثاني: قباسـها على ( سَجَدَات)، و (جَفَنَات)؛ للثََََّهَ الصُّوري في الصنّيغَة.

الثالث: وهـو أَفْوَى في الاحتجـاج لهُذَيْلْ وهـي أنَّ

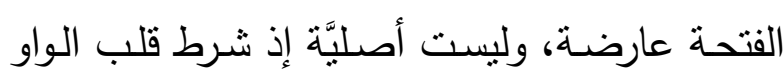

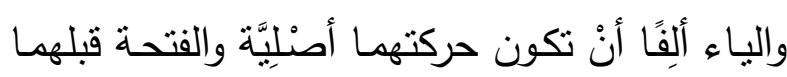
كذلك (97) ، فإذا كانت الفتحة عارِضـة فلا يُعتّدّ بها

(94) ينظر، ابن جني، المحتسب: $184 / 3$ ، 57 ، 58 ، ، الخصائص: 184/3 ، ابن يعيش، شرح المفصل: 5/ 30، 30، ابن مالك،

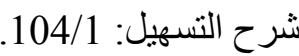

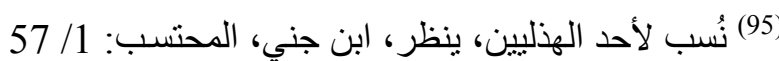

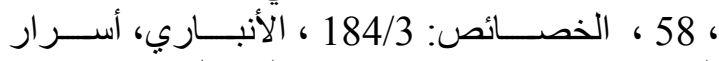

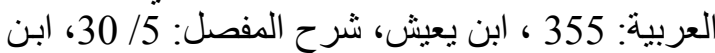

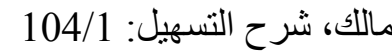

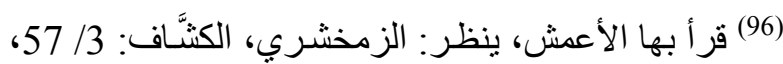

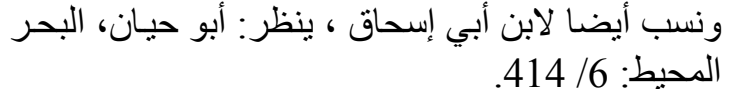
(977) ينظر : ابن جني، سر الصناعة: 795/2 ، 796 
ج - وكذللك عادلوا بين( فَعْل) و (فَعَل) فيى جمَ

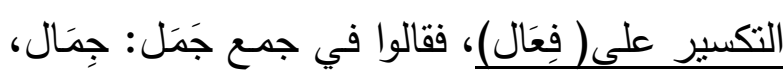

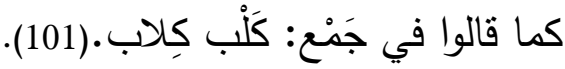

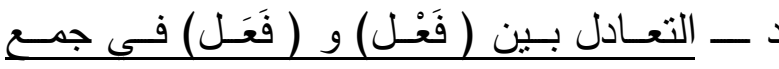

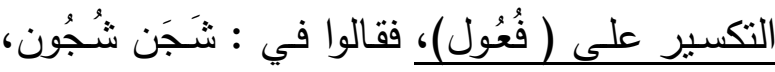

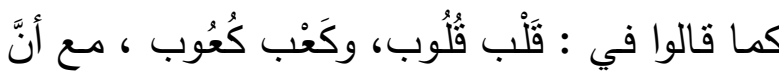

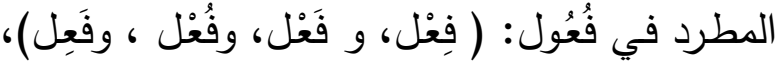

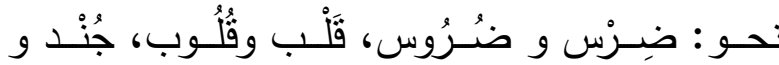

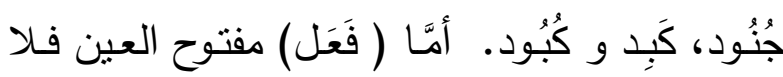

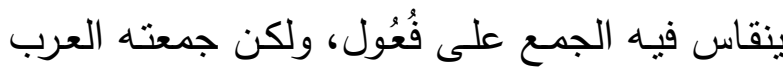

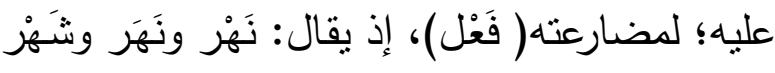

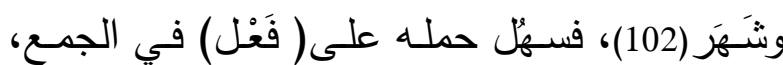

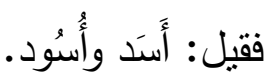

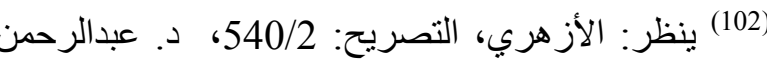

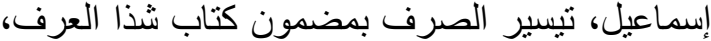

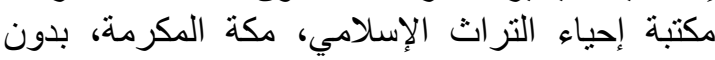

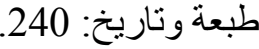


حيث أجرى المنفصـل مجرى المنصـل وهو (رَبُ

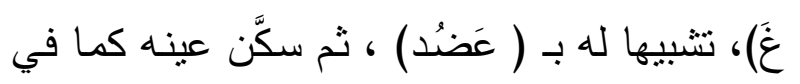

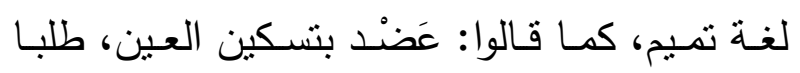
للتخفيف. لتهيم ـ كما يمكن تفسير بعض المواضع التي اصطلح

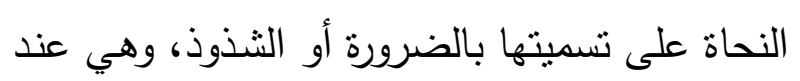

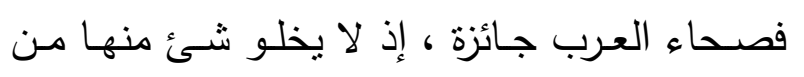

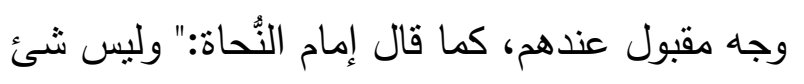
يضـطرون إليـهـ إلا وهـم يحساولون بــهـ وجهـا" (103).

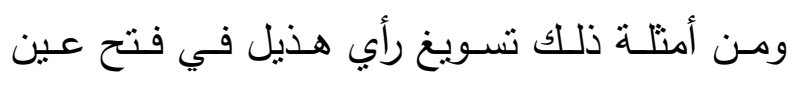

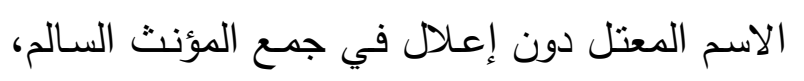

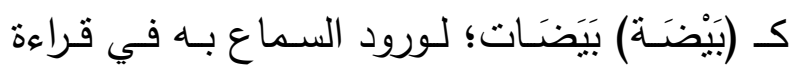

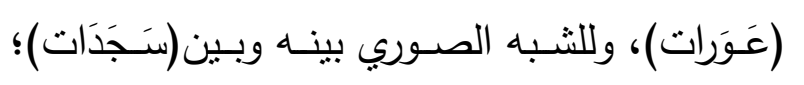

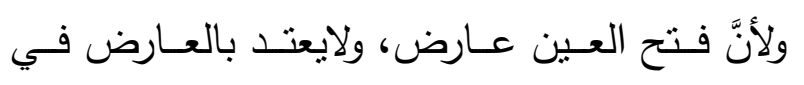

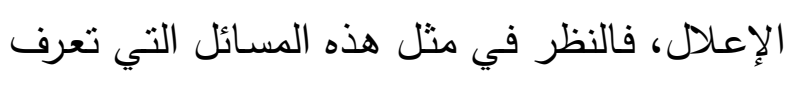

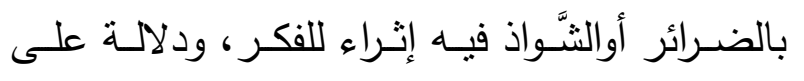
شجاعة مَنْ بِتعمله مِنَ العرب.

32/1 (103)
الخاتمة
ظهرت لي بعد الدراسة والبحث النتائج الآتية:

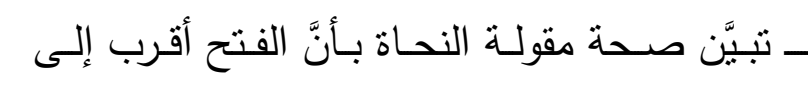

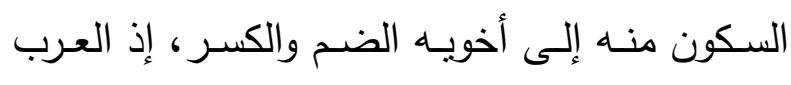 يفرّون من الضم والكسر إلى الفتح والسكون ؛ طلبًا

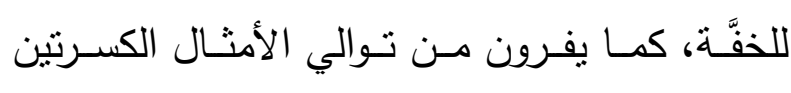

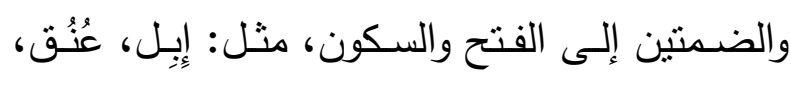 فيقال: إِبْل، وعُنْقَ، وفي سُرُر : سُرَر . - إنَّ الخفَّة صفة لازمة لهما إعرابا وبناء، وفي غير الإعراب والبناء.
ـ للسكون نوعان: أصليّ وعارض، فالأصلي يكون في المبنيَّات، والعارض في التركيب الإسنادي في ني

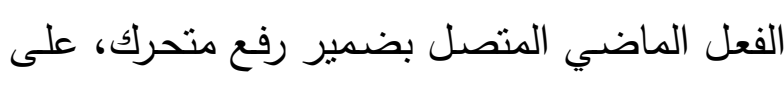 الرأي القائل بينائهه على الفتح المقدر ، والمضــارع

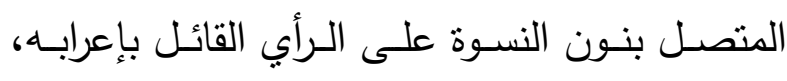 وكذلك الفعل المضارع المجزوم، وفي الوقف، ويأني

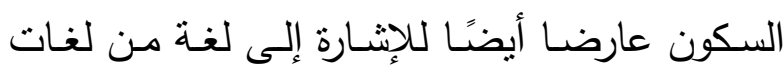

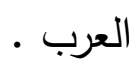 ـ إنَّ الوقوف على مـواطن تقارب الفتح والسكون

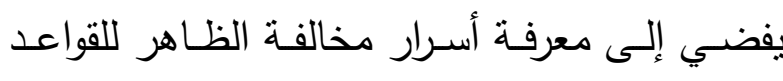

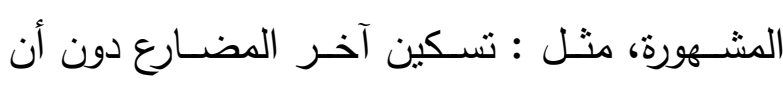 يسبق بجازم، كقول الثاعر : * فاليومَ أَثْرَبْ غَبِرَ مُسْتَحْقِبِ




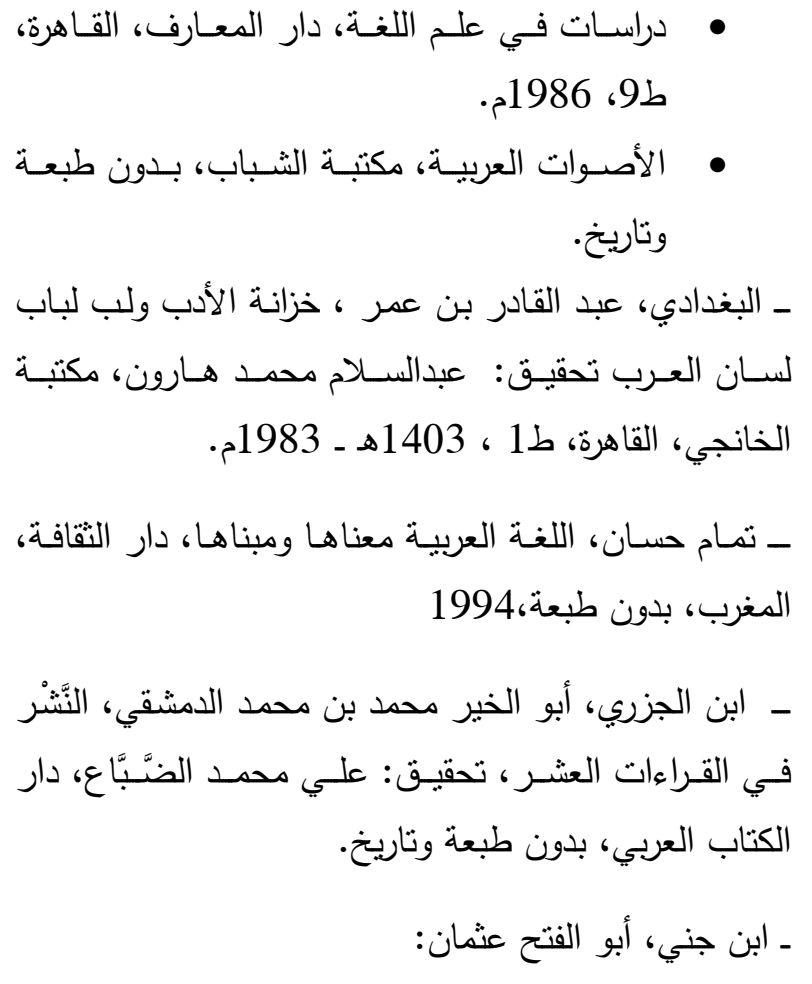

\section{قائمة المصادر والمراجع}

ـ إبراهيم مصطفى، إحياء النحو، القاهرة، ط1، 1913م 1937م،

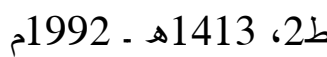

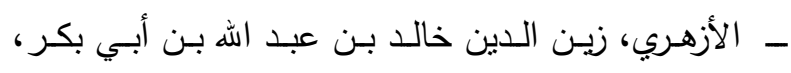

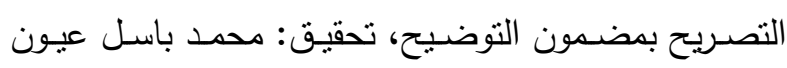

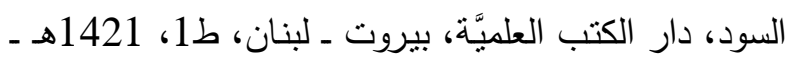

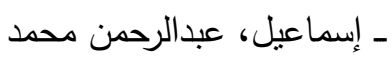

• تيسير الصرف بمضمون كتاب شذا العرف، مكتبة

إحياء التراث الإسلامي، مكة المكرمة، بدون طبعة

وتاريخ.

• الحركات والسكون في لغة الضاد دلالتها، أسرارها،

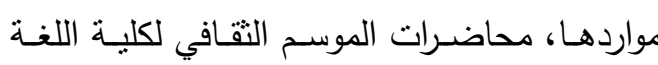

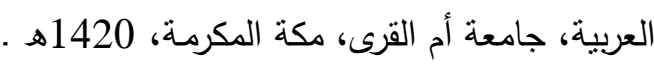

1999م.

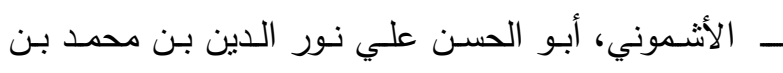
عيسى، منهج السالك إلى ألفية ابن مالك (شرح الأثمعوني)،

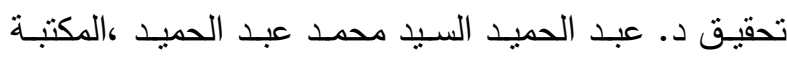
الأزهرية للتراث ـ القاهرة ، د. ت. ـ الأنباري، عبد الرحمن كمال الدين بن محمد

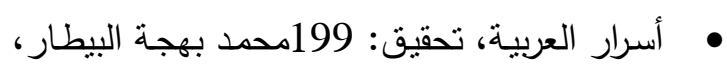

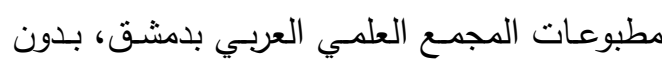
طبعة وتاريخ

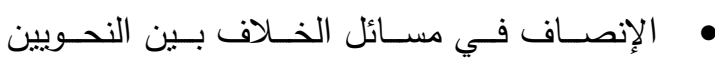

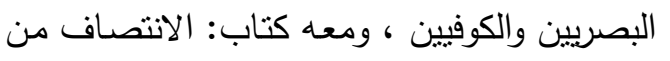

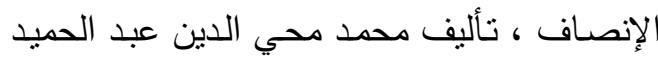

،دار إحباء التزاث العربي، بدون طبعة وتاريخ.

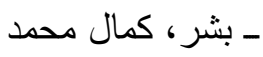




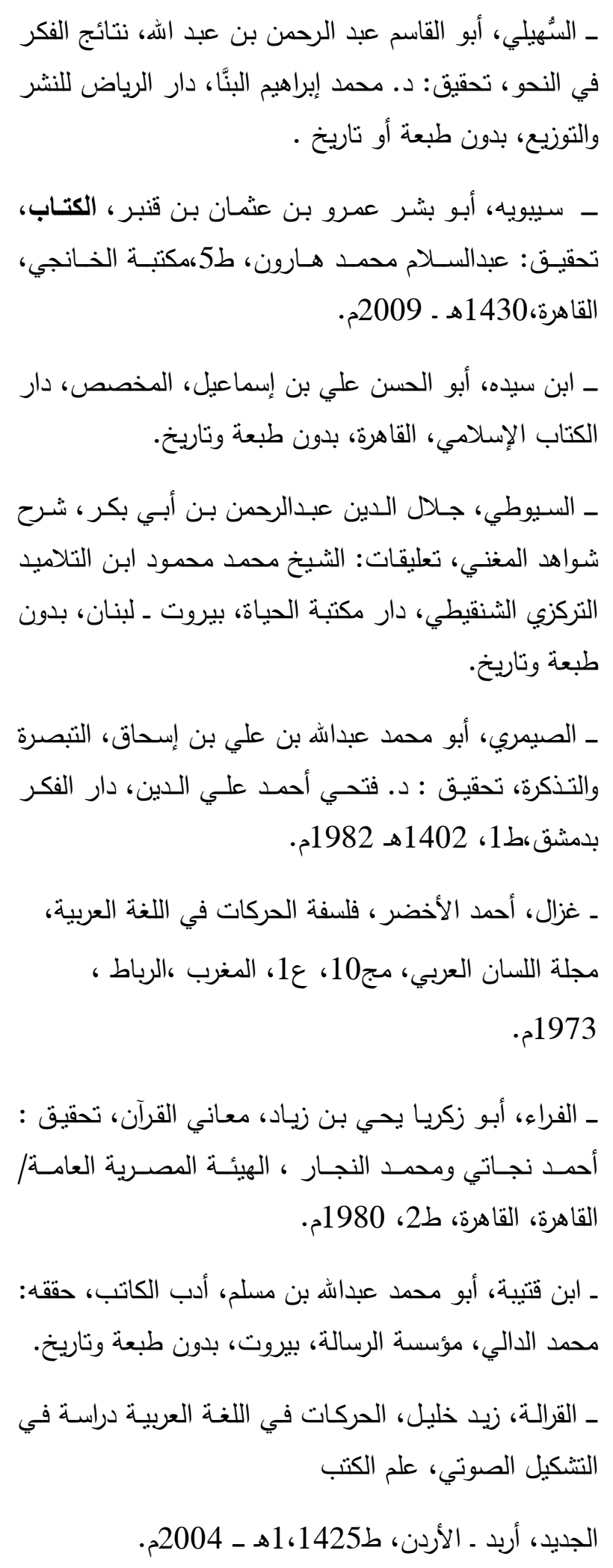

ـ الفراء، أبو زكريا يحي بن زياد، معاني القرآن، تحقيق :

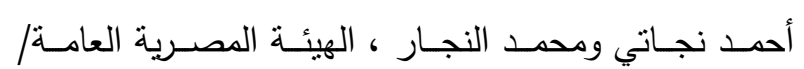

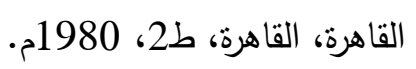

ـ ابن قتيبة، أبو محمد عبداله بن مسلم، أدب الكاتب، حققه: محمد الدالي، مؤسسة الرسالة، بيروت، بدون طبعة وتاريخ. ـ القرالة، زيد خليل، الحركات في اللغة العربيـة دراسـة في

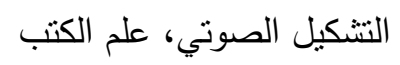
الجديد، أربد ـ الأردن، ط1425،1،هـ ـ 2004م.

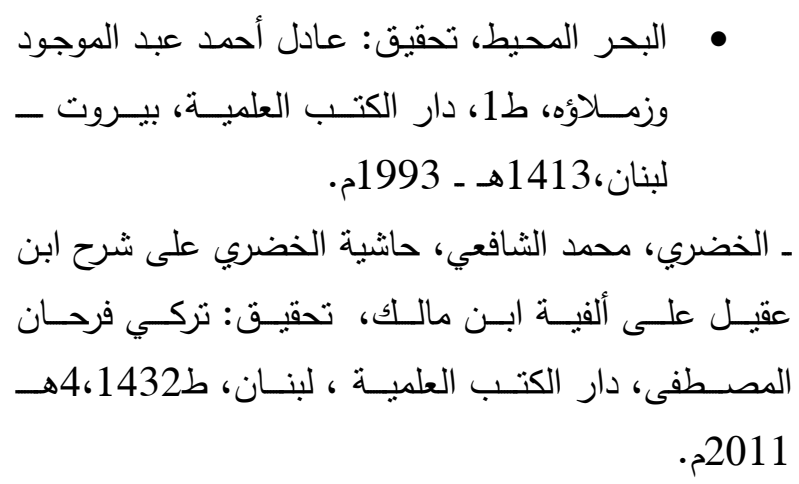

ط1، 1420هـ 


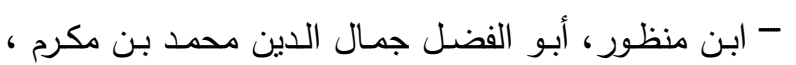

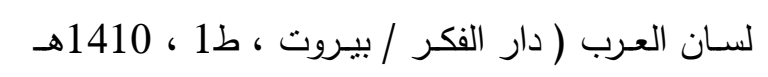

$\cdot($ 199

- ابن هشام، أبو محمد عبداله جمال الدين بن يوسف:

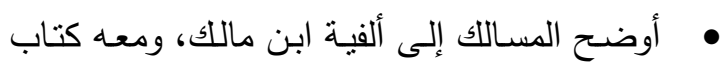
عدة السالك إلى تحقيق أوضـح السسالك، تأليف:

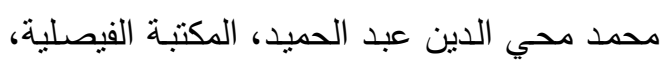
مكة المكرمة، بدون طبعة أو تاريخ.

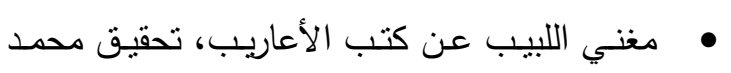

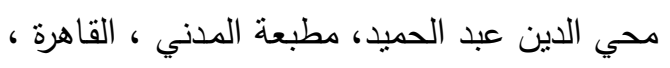
بدون طبعة أو تاريخ.

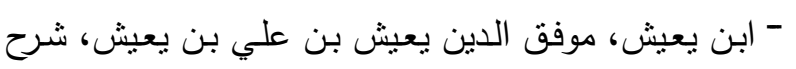
المفصل، عالم الكتب، بيروت، بدون طبعة وتاريخ.
ـ القرطبي، أبوعبداله محمد بن أحمد الأنصـاري ، الجامع

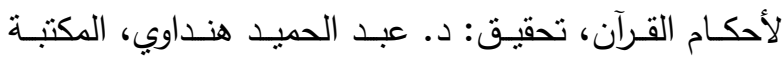

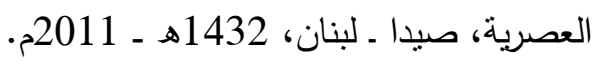
ـ كمال محمد بشر، الأصوات العربية، مكتبة الثباب، بدون

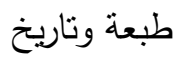

ـ اللبدي ، محمد سمير نجيب ، معجم المصطلحات النحوية

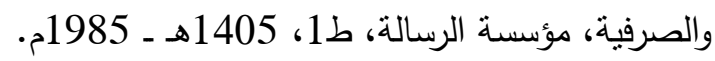
ـ ابن مالك، جمال الدين محمد بن عبد الله بن عبد الله

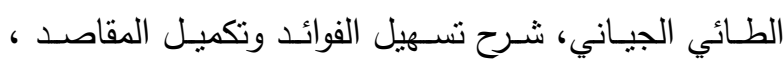

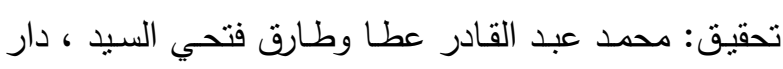
الكتاب العلمية، لبنان ـ بيروت ، ط2 ، 2009م .

ـ المبرد، أبو العباس محمد بن يزيد: المقتضب ، تحقيق :

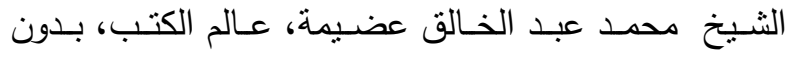

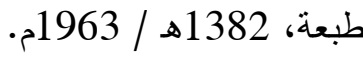

ـ المعجم الوسيط، مجمع اللغة العربية، ط3، بدون تاريخ • 


\title{
Closeness features of al-fath and al-sukoon in the Arabic Grammar
}

Widad Ahmad Abdullah al-Qahtani

\author{
King Saud University
}

Abstract The present research entitled " Closeness features of al-fath and al-sukoon in the Grammar of Arabic " aims at discovering the relationship that brings closer the two opposite marks, namely, al-

Fath (the vowel /a/) and al-Sukoon (absence of a vowel). The study focuses on the Arab grammarians' views and summarizes such features in the following key areas:

- Occurrence as case endings in the declinable and non-declinable for simplification purposes.

Alternative use in the same position.

- Equal use in certain positions such as the medial Imala vowel and Jumo'a al-takseer (Broken plurals).

Among its findings, the study identifies the subtleties for not respecting certain grammatical rules. For example, cases when the present simple verbs are used in the jussive without the presence of the necessary particle. Additionally, the study explains certain matters that the grammarians call the necessity or the exception.

Keywords: Arabic grammar - al-Fath - al-Sukoon. 